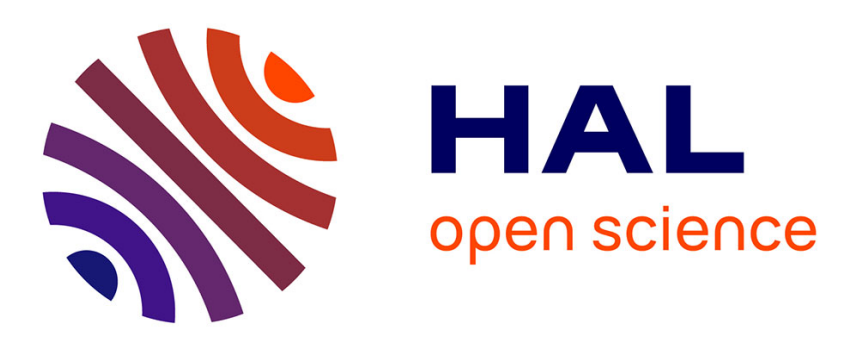

\title{
Talus slope characterization in Tasiapik Valley (subarctic Québec): Evidence of past and present slope processes
} Samuel Veilleux, Najat Bhiry, Armelle Decaulne

\section{To cite this version:}

Samuel Veilleux, Najat Bhiry, Armelle Decaulne. Talus slope characterization in Tasiapik Valley (subarctic Québec): Evidence of past and present slope processes. Geomorphology, 2020, 349, pp.106911. 10.1016/j.geomorph.2019.106911 . hal-03170489

\section{HAL Id: hal-03170489 \\ https://hal.science/hal-03170489}

Submitted on 16 Mar 2021

HAL is a multi-disciplinary open access archive for the deposit and dissemination of scientific research documents, whether they are published or not. The documents may come from teaching and research institutions in France or abroad, or from public or private research centers.
L'archive ouverte pluridisciplinaire HAL, est destinée au dépôt et à la diffusion de documents scientifiques de niveau recherche, publiés ou non, émanant des établissements d'enseignement et de recherche français ou étrangers, des laboratoires publics ou privés. 


\title{
Talus slope characterization in Tasiapik Valley (subarctic Québec): Evidence of past and present slope processes
}

\author{
Samuel Veilleux ${ }^{\mathrm{a}, \mathrm{b}, *}$, Najat Bhiry ${ }^{\mathrm{a}, \mathrm{b}}$, Armelle Decaulne $^{\mathrm{c}}$ \\ a Département de géographie, Université Laval, Québec, Canada \\ b Centre d'études nordiques, Université Laval, Québec, Canada \\ ' CNRS, Laboratoire LETG, Université de Nantes, LabEx DRIIHM, France
}

\section{A R T I C L E I N F O}

\section{Article history:}

Received 6 June 2019

Received in revised form 14 October 2019

Accepted 14 October 2019

Available online 18 October 2019

Keywords:

Morphometry

Slope dynamics

Snow avalanches

Periglacial

Nunavik

\begin{abstract}
A B S T R A C T
Topographic, granulometric, morphometric, petrographic and vegetation surveys were conducted on the slopes of Tasiapik Valley, near Umiujaq (Nunavik), to document mass wasting processes and their geomorphological impact. Talus slopes, widespread at the foot of the steep rockwalls of Tasiapik Valley, are an important landscape feature in the area. The lithology of the slope deposits attest their local origin, namely the result of rockfalls coming from the adjacent wall. Locally, poor vegetation covering the clasts exhibits recently fallen debris; elsewhere, dense shrub cover has colonized the slopes demonstrating the low activity nowadays. On-going periglacial processes have led to extensive dismantling of the rockface, enabling for debris supply. Following the last deglaciation, paraglacial processes have potentially favoured slope instabilities. The use of automatic cameras during the winter 2017-2018 resulted in the observation of many snow-avalanche events; however few rockfall events have been observed. Spring snow avalanches have carried rock debris to the talus at the foot of the slope; snow also enabled debris redistribution on the slopes.
\end{abstract}

\section{Introduction}

Northern landscapes have undergone many changes since their deglaciation. In particular, paraglacial conditions (e.g. glacioisostatic rebound and rockface dismantlement) induced talus slope formation by supplying debris through the pressure release on rock fractures and freeze-thaw processes (Ballantyne and Benn, 1994; Matsuoka and Sakai, 1999; Ballantyne, 2002; Matsuoka, 2008).

Nunavik is part of the low-Arctic region of eastern Canada and its landscape consists of low hills, basins and plateaus. The few studies that have been conducted in this vast region have demonstrated the occurrence of slope processes on slopes less than $100 \mathrm{~m}$ high (Belzile, 1984; Bégin and Filion, 1985; St-Cyr, 1986; Marion et al., 1995; Germain and Martin, 2012; Germain, 2016). Recent studies (Decaulne et al., 2018; Bhiry et al., 2019) conducted at Wiyâshâkimî Lake in Tursujuq National Park (Nunavik) showed that talus slope formation started after deglaciation at about $4600 \mathrm{BP}$, and that slope processes are still active today. Some of the villages in Nunavik (Salluit, Kangiqsujuaq and Kangiqsualujjuaq) are located within

\footnotetext{
* Corresponding author at: 2405, rue de la Terrasse, Université Laval Québec, Québec G1V 0A6, Canada.

E-mail address: samuel.veilleux.4@ulaval.ca (S. Veilleux).
}

glacial valleys with prominent slopes, while other villages (Umiujaq) are situated near high cuesta relief $(\sim 230 \mathrm{~m})$. Accordingly, it is crucial to document slope dynamics and to evaluate associated risks on the local population, visitors and infrastructures. For instance, in Kangiqsualujjuaq (northeastern Nunavik), a dreadful snow avalanche hit the gymnasium of Satuumavik school during the 1999 New Year's Eve celebrations, causing the death of 9 people and injuring 25 (Bérubé, 2000; Lied and Domaas, 2000; Germain, 2016). However, no extensive research has been conducted on slope processes in the Umiujaq area (including snow avalanches, landslide and rockfalls), their triggering factors, their occurrence and their runout distance. General conditions are conducive for bedrock dismantling and mass wasting, even with limited slope heights, but additional knowledge about slope processes is still required.

The main objective of the study is to document landforms organisation built by gravitational processes in Tasiapik Valley and their contribution to talus development based on geomorphological surveys. This study discusses slope evolution during the Holocene, from the retreat of the Laurentide Ice Sheet in the area to the present-day, highlighting the potential risk at the valley bottom. 

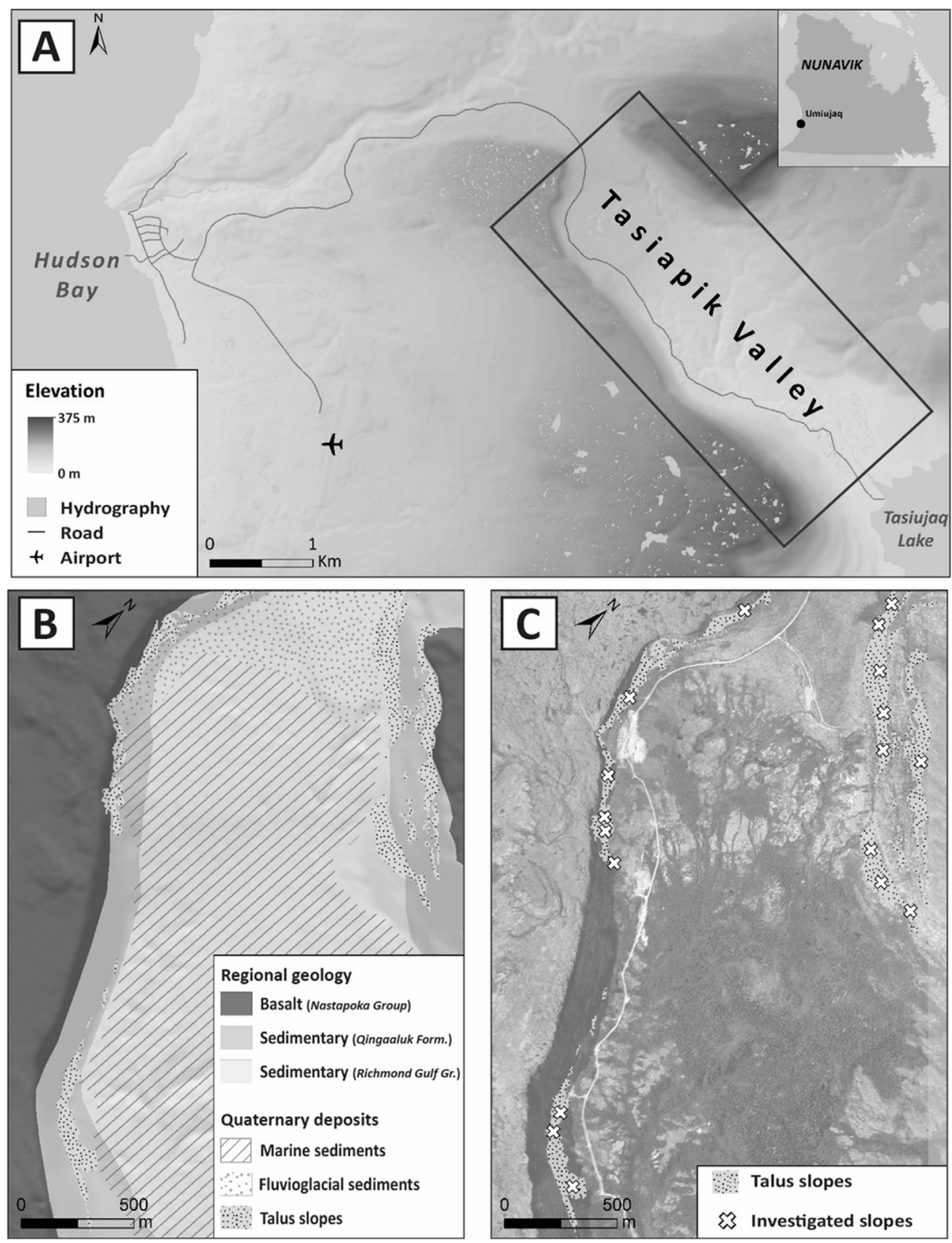

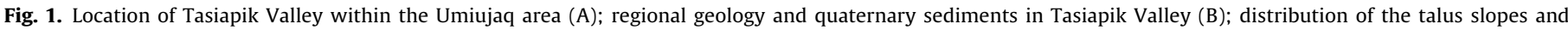
investigated slopes (C). Sources of background images: MRNF (A, B), UMI orthomosaic (2010) (C).

\subsection{Regional setting}

Tasiapik Valley ( $56^{\circ} 33^{\prime} \mathrm{N}, 76^{\circ} 28^{\prime} \mathrm{W}$ ) is located $5 \mathrm{~km}$ east of the Inuit village of Umiujaq, on the east coast of Hudson Bay in Nunavik, Québec (Fig. 1a). It is approximately $4.5 \mathrm{~km}$ long and $1.5 \mathrm{~km}$ wide, following a northwest-southeast orientation. At the southeastern end of the valley lies Tasiujaq Lake (formerly named GuillaumeDelisle Lake or Richmond Gulf), a $691 \mathrm{~km}^{2}$ brackish water body connected with the Hudson Bay by a narrow cataclinal channel called Le Goulet (ARK, 2007). The lake is part of Tursujuq National Park, created in 2013.

The regional geology is characterized by a Paleoproterozoic volcano-sedimentary sequence lying unconformably on the Precambrian shield (Fig. 1b). The volcano-sedimentary sequence includes limestone, quartz arenite, dolomite and sandstone strata (Qingaaluk Formation) underlying a thick $(\sim 15 \mathrm{~m})$ basalt layer (Nastapoka Group) dipping westward (Stockwell et al.,
1979; Chandler and Schwarz, 1980; Chandler, 1988; Eaton and Derbyshire, 2010). This asymmetrical monoclinal relief (cuesta) consists of a gentle western slope and a steep eastern slope and extends over $650 \mathrm{~km}$ along the east coast of Hudson Bay (Dionne, 1976; Guimont and Laverdière, 1980). Tasiapik Valley lies at the frontslope of the cuesta on its southwestern side, whereas the northeastern side consists of a residual butte called Umiujaaluk Hill.

Quaternary deposits on the east coast of Hudson Bay are the result of a succession of sedimentary environments following the retreat of the Laurentide Ice Sheet at about 8200 cal. BP (HillaireMarcel, 1976; Allard and Séguin, 1985; Lavoie et al., 2012) (Fig. 1b). Lowlands below $271 \mathrm{~m}$ a.s.l, the altitudinal limit of the postglacial Tyrrell Sea in Tasiujaq Lake area (Fraser et al., 2005; Lavoie et al., 2012), are covered by deep-water and shallow-water marine sediments, and littoral deposits (raised beaches) that were formed during stages of rapid glacio-isostatic uplift (Hillaire-Marcel, 1976). 
A glaciomarine fan complex lies in the upstream part of the valley. It consists of fluvioglacial material that was deposited during a stillstand of the ice margin around $8000 \mathrm{cal}$. BP (Lajeunesse and Allard, 2003b).

The study area has a cold subarctic climate and it is located in the discontinuous permafrost zone (Allard and Lemay, 2012). Mean annual air temperature recorded between 2013 and 2017 varies between -5.6 and $-4.2^{\circ} \mathrm{C}$, with maxima of $23^{\circ} \mathrm{C}$ and minima of $-36^{\circ} \mathrm{C}$ (Fortier, 2017). Mean annual precipitation is approximately $500 \mathrm{~mm}$, with 40\% falling as snow (Ménard et al., 1998). The Umiujaq area is located at the edge of the shrub and forest tundra zones; low shrubs, ericaceous plants and lichens cover the upstream part of Tasiapik Valley, while dense forest cover occupies the downstream part (Payette, 1983). Shrub cover has expanded significantly (shrubification) during the $20^{\text {th }}$ century (Ménard et al., 1998; Provencher-Nolet et al., 2014; Pelletier et al., 2018).

The SW side of Tasiapik Valley has a near-vertical rockwall. It is approximately $50 \mathrm{~m}$ high in the upstream part of the valley, but it increases to $230 \mathrm{~m}$ near Tasiujaq Lake in the downstream part. Slope deposits lie at the base of the escarpment, connecting the rockwall to the valley floor, but have also accumulated on basaltic rocky outcrops in the uppermost part of the rockwall (Fig. 1c). The NE side features a step-like topography, with slope deposits either located at the base of the slope or perched on basaltic and sedimentary rocky outcrops. A gravel road connecting Umiujaq to Tasiujaq Lake follows the cuesta frontslope on the SW side.

\subsection{Methods}

For this study, 18 talus slopes were investigated, on the SW and NE sides of Tasiapik Valley (Fig. 1c). Data were collected over four field campaigns during the summers of 2016 (August), 2017 (August) and 2018 (June and August). Several slope deposits were identified by satellite imagery prior to initiating fieldwork. Two sets of orthophotos from Québec's Ministère des Ressources naturelles et de la Faune (MRNF) were used, one dating from 2004 (scale $1 / 10,000,25 \mathrm{~cm}$ resolution) and the other from 2010 (scale $1 / 10,000,15 \mathrm{~cm}$ resolution).

Topographic surveys were conducted along 18 longitudinal transects using a Leica DGPS (Differential Global Positioning System). Waypoints were recorded from the apex of the slope deposits to their base, perpendicular to the rock face. Data were processed in ArcGIS and Excel to produce topographic profiles, revealing the microtopographic features such as inflection and texture in accurate details. The estimation of the stage of evolution is carried out from the Ho/Hi ratio, where Ho corresponds to the height of the talus slope and Hi to the total height of the slope including the rockwall (Francou, 1988; Sellier, 1992). The ratio gives an overview of the exhaustion of the remaining rockwall (debris source) in concomitance with the talus slope formation on a longer timescale, namely since the last deglaciation. For example, a ratio approaching 1 indicates an advanced slope development stage due to the low height of the residual wall compared to the height of the talus slope.

Topographic data and satellite imagery were used to measure rockfall runout distances (horizontal travel distance) calculated from the source area to the farthest slope debris. In addition, the reach angle, calculated from the source-area to the farthest slope debris, and the shadow angle, calculated from the apex of the talus to the farthest slope debris, were documented to provide information about the extent of slope processes in the area.

On 12 of the 18 longitudinal transects, granulometric and petrographic surveys were conducted by sampling 25 randomly selected rock fragments at intervals of $10-15 \mathrm{~m}$ along the transects. Debris were measured along three axes: length (a-axis), width (b-axis) and thickness (c-axis). Measurements were compiled in Excel and then analyzed to produce descriptive statistics. Morphometric indices were also calculated from these measures (Pérez, 1989, Hétu and Gray, 2000). The flattening index (Fi) is calculated as follows:

$F_{i}=\frac{a+b}{2 c}$

where $a$ corresponds to the length, $b$ to the width and $c$ to the thickness of the fragment (Cailleux, 1947). A high Fi value indicates that the debris has a flatter shape. The elongation index $(L i)$ is calculated as follows:

$L_{i}=\frac{a}{b}$

where $a$ and $b$ correspond to the length and width of the fragment (Schneiderhöhn, 1954). A high $\mathrm{Li}$ value indicates that the debris tends to be elongated. Finally, the sphericity index $(\mathrm{Si})$ is calculated as follows:

$S_{i}=\left(\frac{b c}{a^{2}}\right)^{\frac{1}{3}}$

where $a, b$ and $c$ correspond to the length, width and thickness of the fragment (Krumbein, 1941). A value Si approaching 1 indicates that the debris has a more massive shape, spherical in the case of a rounded fragment and cubic for an angular fragment. These indices document the falling behavior of clasts, since spherical debris are prone to rolling, while elongated flat debris are more likely to slide. Petrographic surveys provide lithological data for the measured fragments. Their origin, either local (associated with the local slope development) or exogenous (generally from glacial transport and deposition), is closely related to their lithology, thus their general shape, and their position on the slope. The edges of the debris were characterized, with a view to determining their origin: an angular fragment has undergone very little erosion, indicating a short transportation distance/local source, while debris transported by glaciers or reworked in the Tyrrell Sea has a pronounced rounded shape.

Vegetation cover was described at each sampling station in order to assess recent and current process activity. Hierarchical values were attributed to each station based on the type of vegetation and the estimated percentage of coverage on the debris, providing relative age-estimates:

1) Fresh debris: no lichen species observed on the clast;

2) Recent debris: some lichen species observed on the clast;

3) Medium-aged debris: several lichen species partially cover the clast;

4) Old-aged debris: several species of lichens and mosses partially cover the clast;

5) Very old-aged debris: several species of lichens and mosses totally cover the clast; potentially also covered with low shrubs.

Vegetation classification values and $\mathrm{Ho} / \mathrm{Hi}$ ratio values were used to estimate the stage of slope development. The addition of these two values gives an overview of the slope evolution from both short term (vegetation) and long term (Ho/Hi) perspectives. Values of 1 to 5 were assigned to each longitudinal profile according to their $\mathrm{Ho} / \mathrm{Hi}$ ratio, following the Jenks natural breaks classification method (Jenks, 1967); a value approaching 1 indicates a low $\mathrm{Ho} / \mathrm{Hi}$ ratio, thus a younger development stage. The vegetation values (i.e. the lowest - freshest - value per profile, ranked 1 to 5 according to the relative age estimate described above) were added to provide an overall development score. In addition, the age of shrubs at the bottom of talus along the SW-07, SW-08 and SW-09 profiles was determined using dendrochronology on 11 black spruce samples (Picea mariana).

Finally, in order to monitor slope movements on a shorter time scale, three Reconyx PC800 automatic time-lapse cameras were 

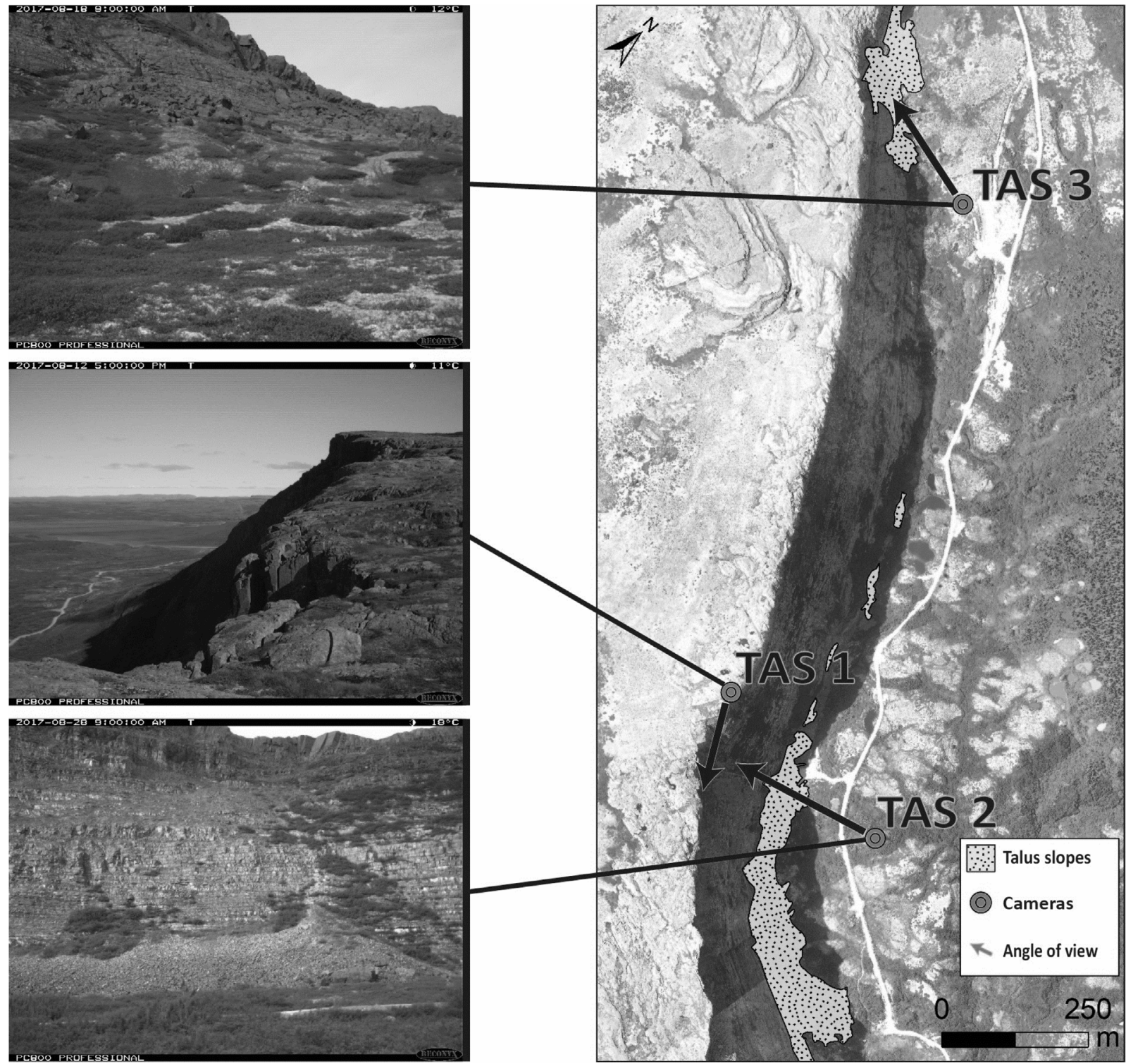

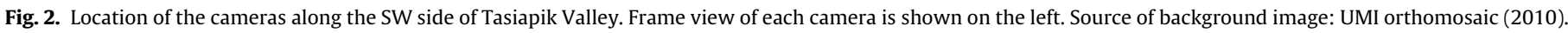

installed on the SW side of the valley in August 2017. One of the cameras (TAS 1 ) is located on the cuesta edge, above the rockwall and talus along the SW-07 and SW-08 profiles (Fig. 2). The latter is covered by a second camera (TAS 2) that is located $300 \mathrm{~m}$ away from the rockwall. A third camera (TAS 3 ) is located further upstream near the base of the talus along the SW-06 profile. Approximately 14,000 photos were taken over a one-year period from August 2017 to August 2018 in the valley. Photos were taken during daytime at one-hour intervals until June 2018 , then at 15 or 30 min intervals (depending on the location) until August 2018.

\section{Results}

\subsection{Topography of slope deposits}

The SW profiles show a steeper slope gradient, with a mean angle of $25.3^{\circ}$ and a median angle of $26.3^{\circ}$, while the NE profiles have a mean angle of $21.2^{\circ}$ and a median angle of $17.5^{\circ}$ (Table 1 ; Fig. 3). A slight or distinct concavity of the talus slope is apparent on six of the nine SW profiles, while the SW-01 and SW-06 profiles are virtually linear. The SW-09 profile shows a more complex shape (linear proximal part and chaotic distal part). On the NE side, there is no distinct concave profile, yet seven of the nine profiles show either a slightly concave or a linear shape, while the NE-04 and NE07 profiles respectively show a complex and a convex shape. Four profiles (SW-07, SW-08, SW-09 and NE-09) exhibit a strong basal concavity (Fig. 3).

\subsection{Relative dating of slopes}

The mean Ho/Hi index on the SW (0.36) and NE sides (0.25) indicates that the remaining rockwall is generally higher than talus slopes (index < 0.5) (Table 2). However, the step-like topography on the NE side, compared to the near-vertical rockwall on the SW side, could mean that the NE side has reached a more advanced stage of development. Talus slopes near the southern margin of both sides (along the SW-07, SW-08, SW-09 and NE-09 profiles) are located under high vertical rockwalls with $\mathrm{Ho} / \mathrm{Hi}$ index below 0.2 , thus indicating a younger development stage. The SW-04 and SW-05 profiles indicate an older stage than the other SW profiles, with respective index values of 0.56 and 0.62 . 
Table 1

Topographic parameters of the investigated slopes.

\begin{tabular}{|c|c|c|c|c|}
\hline Profiles & Slope angle $\left(^{\circ}\right)$ & Mean angle $\left(^{\circ}\right)$ & Median angle $\left({ }^{\circ}\right)$ & Inflection \\
\hline SW-01 & 18.4 & & & linear \\
\hline SW-02 & 28.1 & & & slightly concave \\
\hline SW-03 & 28.3 & & & slightly concave \\
\hline SW-04 & 19.3 & & & concave \\
\hline SW-05 & 24.9 & 25.3 & 26.3 & concave \\
\hline SW-06 & 27.1 & & & linear \\
\hline SW-07 & 26.3 & & & concave \\
\hline SW-08 & 30.0 & & & concave \\
\hline SW-09 & 25.2 & & & complex \\
\hline NE-01 & 14.2 & & & linear \\
\hline NE-02 & 12.3 & & & slightly concave \\
\hline NE-03 & 17.5 & & & slightly concave \\
\hline NE-04 & 16.1 & & & complex \\
\hline NE-05 & 17.4 & 21.2 & 17.5 & linear \\
\hline NE-06 & 31.8 & & & linear \\
\hline NE-07 & 27.1 & & & convex \\
\hline NE-08 & 23.2 & & & linear \\
\hline NE-09 & 31.6 & & & slightly concave \\
\hline
\end{tabular}

Table 2

Calculation of $\mathrm{Ho} / \mathrm{Hi}$ index.

\begin{tabular}{|c|c|c|c|c|c|c|}
\hline Profiles & Talus base elev. (m) & Talus apex elev. (m) & Ho value & Rockwall elev. (m) & Hi value & $\mathrm{Ho} / \mathrm{Hi}$ index \\
\hline SW-01 & 171.3 & 187.6 & 16.3 & 222 & 50.7 & 0.321 \\
\hline SW-02 & 147.3 & 178.3 & 31.0 & 216 & 68.7 & 0.451 \\
\hline SW-03 & 146.3 & 176.8 & 30.5 & 208 & 31.7 & 0.494 \\
\hline SW-04 & 151.4 & 183.2 & 31.8 & 208 & 56.6 & 0.562 \\
\hline SW-05 & 148.0 & 187.9 & 39.9 & 212 & 64.0 & 0.623 \\
\hline SW-06 & 127.4 & 159.2 & 31.8 & 212 & 84.6 & 0.376 \\
\hline SW-07 & 46.5 & 82.0 & 35.5 & 214 & 167.5 & 0.212 \\
\hline SW-08 & 47.6 & 67.2 & 19.6 & 222 & 174.4 & 0.112 \\
\hline SW-09 & 49.6 & 75.9 & 26.3 & 272 & 222.4 & 0.118 \\
\hline NE-01 & 156.1 & 169.9 & 13.8 & 202 & 45.9 & 0.301 \\
\hline NE-02 & 157.2 & 167.3 & 10.1 & 252 & 94.8 & 0.107 \\
\hline NE-03 & 164.6 & 182.8 & 18.2 & 254 & 89.4 & 0.204 \\
\hline NE-04 & 163.0 & 184.3 & 21.3 & 270 & 107.0 & 0.199 \\
\hline NE-05 & 162.1 & 178.1 & 16.0 & 282 & 119.9 & 0.133 \\
\hline NE-06 & 225.6 & 260.8 & 35.2 & 282 & 54.4 & 0.624 \\
\hline NE-07 & 131.7 & 167.5 & 35.8 & 292 & 160.3 & 0.223 \\
\hline NE-08 & 134.6 & 184.0 & 49.4 & 302 & 167.4 & 0.295 \\
\hline NE-09 & 161.2 & 188.8 & 27.6 & 312 & 150.8 & 0.183 \\
\hline
\end{tabular}

Examination of the vegetation covering the surficial debris on the slope deposits revealed the presence and position of few fresh deposits. Most of the debris had a clear vegetation cover on the SW side (Fig. 4). In the apical parts of the talus slopes, various lichens and/or mosses are abundant, while a discontinuous thin strip of herbaceous plants and low shrubs is located at the edge of the rockwall undisturbed by present-day slope activity. Distal parts also feature abundant lichens and mosses on most of the clasts along with thick mosses covering the slope deposits and low shrubs; this trend is especially evident on the SW-07 and SW-09 profiles. A similar trend was observed on the NE profiles, as most sampling stations in the apical part of the talus slopes show medium to old-age status, while sampling stations in the distal parts indicate older-age status. However, debris along the SW-08, NE-06 and NE-09 profiles appear to be more recent, with little overall coverage and the presence of few lichens. Some fresh debris were scattered along most of the profiles (Table 3 ).

By adding up the $\mathrm{Ho} / \mathrm{Hi}$ index values and the vegetation classification values, we can estimate the developmental stage of the slopes. As shown on Fig. 5, the SW-08 and NE-09 profiles seem to be at the youngest developmental stage among all the talus slopes. The $\mathrm{Ho} / \mathrm{Hi}$ index and the vegetation classification values are consistent for some profiles, showing a concomitance for both parameters. For example, the talus slope along NE-09 profile has a low $\mathrm{Ho} / \mathrm{Hi}$ index (0.183) and there is very poor lichen cover on the debris. However, the two parameters proved to be contradictory for some talus slopes, particularly for the SW-09 profiles, due to the overly high rockwall (increased debris supply potential) and the presence of well-developed vegetation (limited debris supply on the talus slope). Both of these findings indicate that the debris supply is sporadic.

\subsection{Source and morphometry of slope deposits}

Three classes of debris were identified along the investigated profiles: 1) basalt, 2) sedimentary rocks (comprising dolomite, limestone, quartz arenite and sandstone), and 3) granitic gneiss (Fig. 6).

On the SW side, sedimentary rock debris comprised $64.5 \%$ of the sampled clasts, whereas basalt debris accounted for $35.4 \%$ and gneiss for $0.07 \%$. Sedimentary rock debris represented a larger proportion on the NE side, accounting for $89.4 \%$ of all clasts, while basalt and gneiss accounted for $6.4 \%$ and $4.2 \%$. Assuming the top basalt layer is $\sim 15 \mathrm{~m}$ thick throughout the valley; those values coincide with the large proportion of sedimentary rock strata available for debris supply on the exposed rockwall. Sedimentary rock strata account for $90 \%(\sim 140 \mathrm{~m})$ of the rockwall $(\sim 155 \mathrm{~m})$ above the SW07, SW-08 and SW-09 profiles. In the upstream part of the SW side, sedimentary rock strata account for $57 \%(\sim 20 \mathrm{~m})$ of the rockwall $(\sim 35 \mathrm{~m})$. On the NE side, the top basalt layer has considerably receded on most of the investigated slopes, revealing rocky outcrops composed of sedimentary rock strata. However, the rockwall 


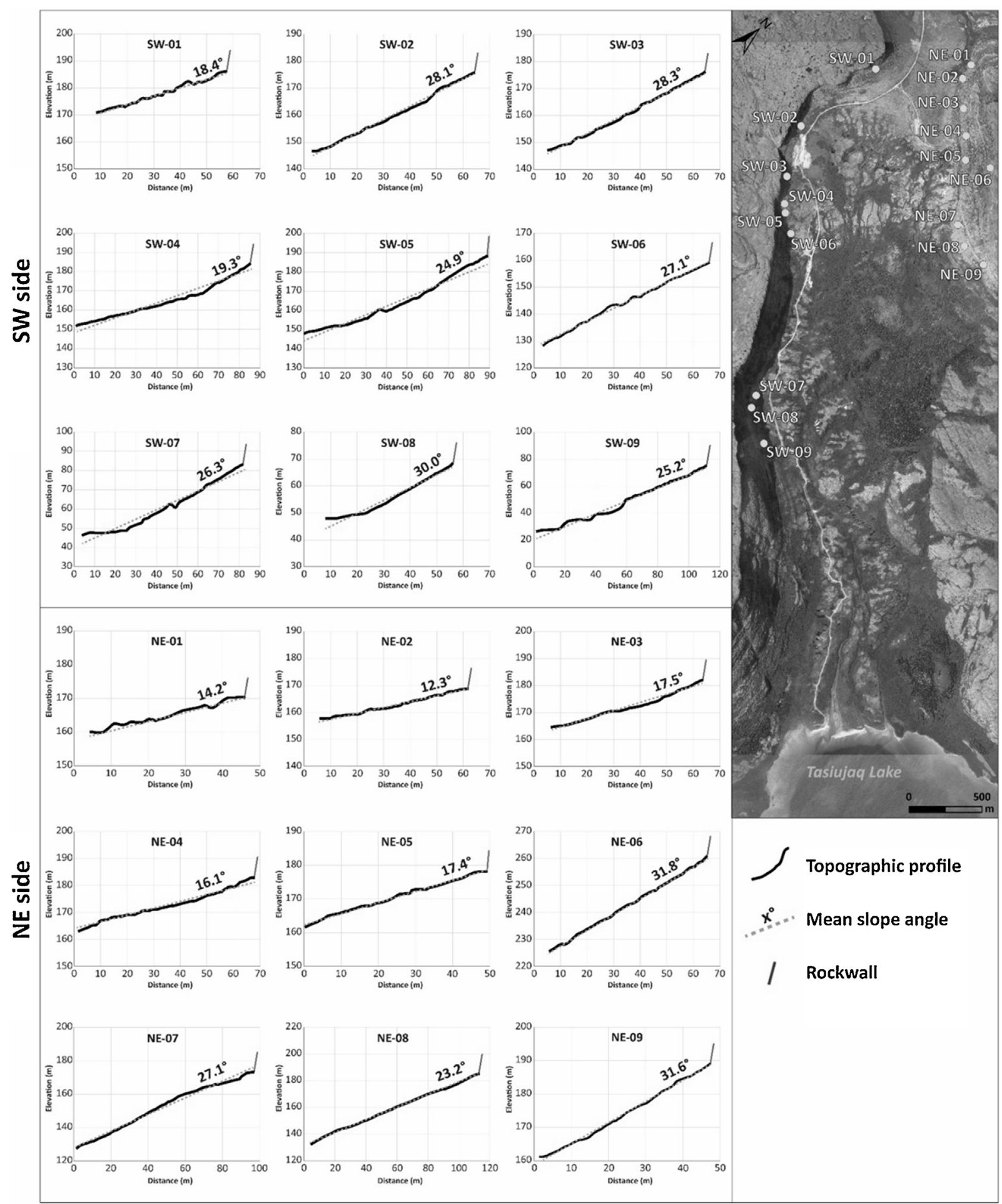

Fig. 3. Longitudinal cross-section of the investigated slopes. Source of background image: UMI orthomosaic (2010).

above the NE-06 profile is mainly composed of basalt (68\% of total height).

By comparing the respective proportions of each lithology at sampling stations along the profiles, many of the slope deposits show consistent ratios of sedimentary rocks and/or basalt debris from the apex to the base of the slope. On the SW side, the proportion of basalt debris varies between $80 \%$ and $84 \%$ throughout the sampling stations on the SW-02 profile and between $14 \%$ and $26 \%$ on the SW-07 profile. On the NE side, the proportion of sedimentary rock debris varies between $80 \%$ and $88 \%$ on the NE-02 profile, while the NE-08 and NE-09 profiles show no difference as sedimentary rock debris compose $100 \%$ of the talus. However, some of the slope deposits show an increasing proportion of basalt material toward the foot of the talus. For example, along the SW08 profile, the basalt debris percentage increases from $17 \%$ at the apex to $37 \%$ at the bottom of the slope; on the SW-09 profile, it increases significantly from $12 \%$ to $100 \%$. Finally, on the NE-06 profile, the basalt debris are only located at the bottom of the talus, whereas the sedimentary rock debris comprises the entire apical part. 


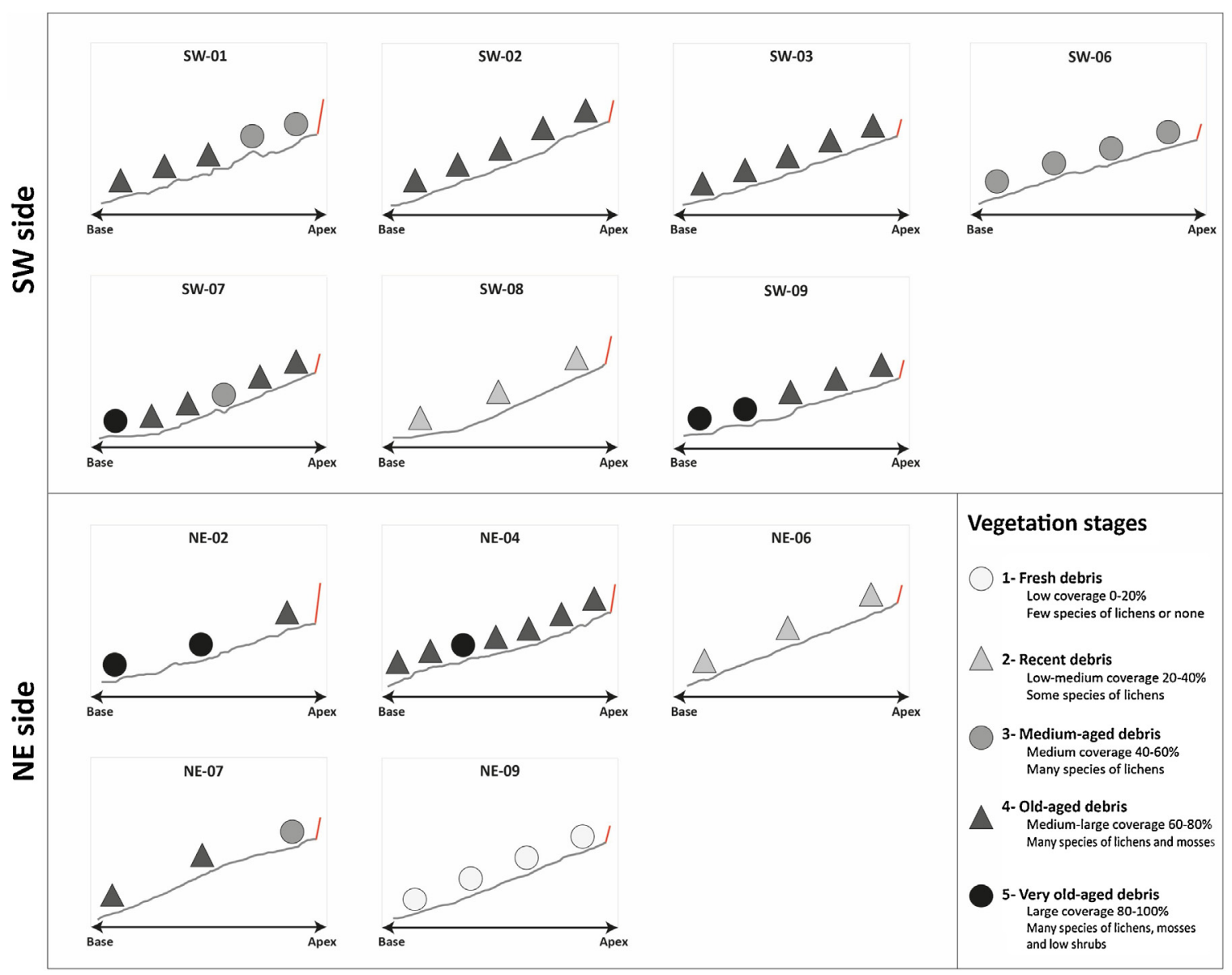

Fig. 4. Vegetation stages along the talus slopes.
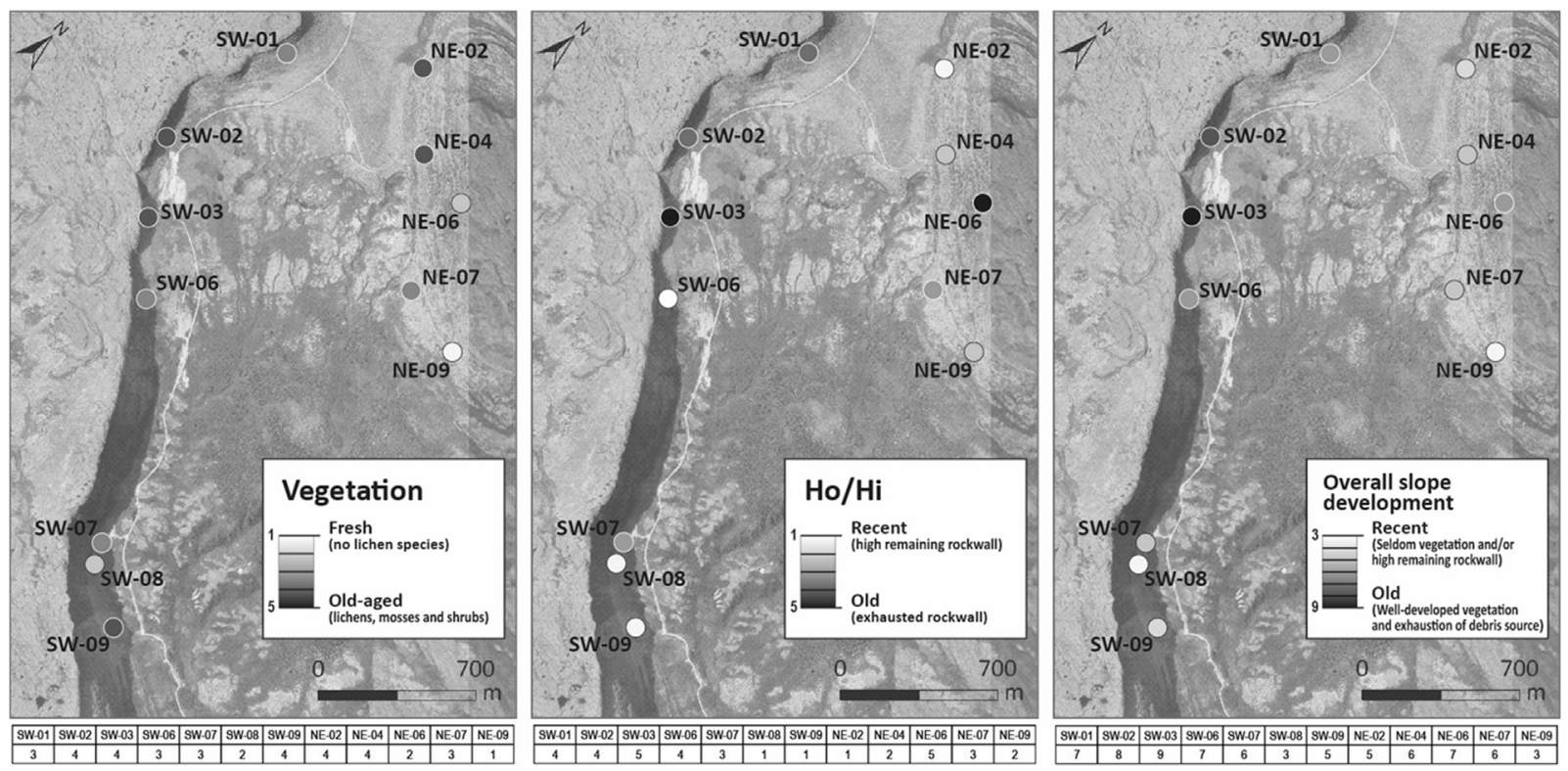

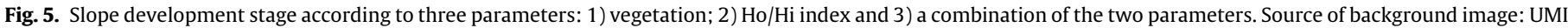
orthomosaic (2010).

Clasts were measured to document the size and morphometry of the slope deposits, and their distribution along the deposits (Fig. 7). On the SW side, the debris (a-axis) range in size from 30 to $154 \mathrm{~cm}$ on average (Table 3). However, standard deviation values show important disparities between the measured clasts, as the largest clasts range from 200 to $1900 \mathrm{~cm}$. In addition, mean flatness index values range from 2.36 to 4.22 . Lengthening and sphericity indices do not vary much, ranging from 1.48 to 1.86 and from 0.54 to 0.65 . On the NE side, sizes range from 83 to $178 \mathrm{~cm}$ on average, while standard deviation values show important disparities between the 
Table 3

Debris size and morphometric parameters along the longitudinal profiles.

\begin{tabular}{|c|c|c|c|c|c|c|c|c|c|}
\hline Profiles & & a-axis $(\mathrm{cm})$ & b-axis (cm) & c-axis $(\mathrm{cm})$ & $\mathrm{b} / \mathrm{a}$ & $c / b$ & Flatness & Lengthening & Sphericity \\
\hline \multirow{6}{*}{ SW-01 } & median & 45.00 & 32.00 & 19.00 & 0.70 & 0.63 & 1.96 & 1.43 & 0.65 \\
\hline & mean & 65.54 & 45.74 & 27.54 & 0.69 & 0.64 & 2.36 & 1.53 & 0.65 \\
\hline & standard dev. & 58.57 & 44.99 & 26.57 & 0.16 & 0.22 & 1.24 & 0.40 & 0.12 \\
\hline & maximum & 450.00 & 350.00 & 180.00 & 0.98 & 1.00 & 10.42 & 2.73 & 0.93 \\
\hline & minimum & 11.00 & 7.00 & 3.00 & 0.37 & 0.11 & 1.10 & 1.03 & 0.38 \\
\hline & range & 439.00 & 343.00 & 177.00 & 0.61 & 0.89 & 9.31 & 1.70 & 0.55 \\
\hline \multirow{6}{*}{ SW-02 } & median & 60.00 & 37.00 & 21.00 & 0.63 & 0.64 & 2.10 & 1.58 & 0.62 \\
\hline & mean & 78.18 & 48.93 & 30.99 & 0.64 & 0.63 & 2.55 & 1.68 & 0.62 \\
\hline & standard dev. & 80.30 & 48.04 & 35.48 & 0.17 & 0.21 & 2.44 & 0.51 & 0.11 \\
\hline & maximum & 600.00 & 350.00 & 290.00 & 1.15 & 1.04 & 27.50 & 3.64 & 0.87 \\
\hline & minimum & 8.00 & 5.00 & 1.00 & 0.28 & 0.05 & 1.17 & 0.87 & 0.26 \\
\hline & range & 592.00 & 345.00 & 289.00 & 0.88 & 0.99 & 26.33 & 2.77 & 0.61 \\
\hline \multirow{6}{*}{ SW-03 } & median & 84.00 & 50.00 & 23.00 & 0.67 & 0.57 & 2.21 & 1.50 & 0.60 \\
\hline & mean & 154.48 & 95.20 & 60.77 & 0.67 & 0.58 & 2.84 & 1.62 & 0.62 \\
\hline & standard dev. & 262.49 & 141.39 & 108.40 & 0.18 & 0.24 & 1.88 & 0.49 & 0.13 \\
\hline & maximum & 1900.00 & 1000.00 & 800.00 & 1.00 & 1.11 & 13.75 & 3.32 & 0.91 \\
\hline & minimum & 8.00 & 7.00 & 3.00 & 0.30 & 0.10 & 1.07 & 1.00 & 0.32 \\
\hline & range & 1892.00 & 993.00 & 797.00 & 0.70 & 1.01 & 12.68 & 2.32 & 0.59 \\
\hline \multirow{6}{*}{ SW-06 } & median & 50.00 & 36.00 & 17.00 & 0.72 & 0.58 & 2.21 & 1.38 & 0.61 \\
\hline & mean & 77.14 & 54.89 & 29.70 & 0.72 & 0.56 & 2.69 & 1.48 & 0.64 \\
\hline & standard dev. & 78.61 & 55.69 & 34.26 & 0.17 & 0.24 & 1.36 & 0.45 & 0.13 \\
\hline & maximum & 470.00 & 310.00 & 190.00 & 1.04 & 1.00 & 7.50 & 3.86 & 0.93 \\
\hline & minimum & 5.00 & 5.00 & 3.00 & 0.26 & 0.15 & 1.06 & 0.96 & 0.33 \\
\hline & range & 465.00 & 305.00 & 187.00 & 0.78 & 0.85 & 6.44 & 2.90 & 0.60 \\
\hline \multirow{6}{*}{ SW-07 } & median & 23.50 & 14.00 & 6.00 & 0.63 & 0.50 & 3.00 & 1.58 & 0.53 \\
\hline & mean & 30.08 & 17.27 & 8.24 & 0.62 & 0.89 & 4.22 & 1.81 & 0.54 \\
\hline & standard dev. & 24.17 & 11.83 & 7.91 & 0.18 & 1.33 & 3.78 & 0.76 & 0.13 \\
\hline & maximum & 206.00 & 100.00 & 70.00 & 1.00 & 10.00 & 29.50 & 6.80 & 0.94 \\
\hline & minimum & 6.00 & 2.00 & 1.00 & 0.15 & 0.04 & 1.10 & 1.00 & 0.21 \\
\hline & range & 200.00 & 98.00 & 69.00 & 0.85 & 9.96 & 28.40 & 5.80 & 0.73 \\
\hline \multirow{6}{*}{ SW-08 } & median & 36.00 & 20.00 & 11.00 & 0.59 & 0.56 & 2.57 & 1.69 & 0.56 \\
\hline & mean & 48.16 & 27.31 & 14.29 & 0.60 & 0.57 & 2.96 & 1.86 & 0.57 \\
\hline & standard dev. & 42.23 & 26.74 & 12.83 & 0.18 & 0.22 & 1.53 & 0.80 & 0.12 \\
\hline & maximum & 280.00 & 223.00 & 100.00 & 1.00 & 1.00 & 11.17 & 10.42 & 0.92 \\
\hline & minimum & 4.00 & 3.00 & 1.00 & 0.10 & 0.09 & 1.07 & 1.00 & 0.19 \\
\hline & range & 276.00 & 220.00 & 99.00 & 0.90 & 0.91 & 10.10 & 9.42 & 0.73 \\
\hline
\end{tabular}

measured clasts. The largest clasts range in size between 350 and $950 \mathrm{~cm}$, while the mean flatness index values range from 2.29 to 3.58. Lengthening and sphericity indices show similar values as the profiles on the SW side, ranging from 1.40 to 1.82 , and from 0.57 to 0.69 . By comparing the calculated index values along all profiles, the clasts tend to have a flatter and more elongated shape in the downstream part of the valley on the SW side (SW-07, SW-08 and SW-09), and along the NE-06 and NE-09 profiles. This morphology is more associated with sedimentary rock debris due to the dismantling of the thin sedimentary layers which represents the majority (84.5\%) of the sampled debris along these profiles (given the larger proportion of sedimentary rock within the rockwall). For most of the profiles, the mean and median a-axis values tend to increase toward the base of the slopes. As for the morphometry indices, 50\% of the profiles show an increasing trend for flatness and sphericity values toward the base of the slope, while the lengthening index of clasts increases from the apex to the base for $75 \%$ of the profiles.

Debris from every sampling station on the SW side were analyzed and described as being either angular or subangular, which indicates their local slope-related provenance, whereas the NE side shows a greater diversity of debris shape. For the NE-02 and NE-04 profiles, rounded/sub-rounded debris are abundant at the base and angular debris are found near the apex of the talus slopes, meaning that slope-related debris have accumulated in the proximal part and mixed with rounded heavily reworked debris toward the distal part.

\subsection{Debris runout}

Several scattered clasts are located in the distal parts of the slopes. These are mostly located on the SW side and some of them were deposited only a few meters from the road. Their angular shape and lithology (mostly basalt) indicate their local sloperelated provenance, by contrast with rounded fluvioglacial/glacial debris.

According to Corominas et al. (2003), the maximum reach angle for small-scale $\left(1-10 \mathrm{~m}^{3}\right)$ rockfalls on an unobstructed path is $48^{\circ}$. Therefore, material falling from the uppermost source area in the rockwall (basalt layer) would theoretically be transported no further than the talus at the bottom of the slope, where the terrain levels out and the shrub vegetation is often denser (Fig. 8). This perfectly matches the very large boulder accumulation on the SW09 profile. However, the reach angle for the farthest basalt debris, located beyond the talus slopes, ranges from $24^{\circ}$ to $40^{\circ}$. These lower reach angles show a greater horizontal displacement of fallen debris, resulting from either a large-scale rockfall $\left(10-100 \mathrm{~m}^{3}\right.$ for a $40^{\circ}$ reach angle; $100-1000 \mathrm{~m}^{3}$ for a $33^{\circ}$ reach angle; $>1000 \mathrm{~m}^{3}$ for a $26^{\circ}$ reach angle) (Corominas et al., 2003) or an external process. For example, there are a dozen large basalt boulders (a-axis $>100 \mathrm{~cm}$ ) located in the distal part of the SW-07 profile at a $30^{\circ}$ angle. However, the volume is not sufficient for such a displacement to result from a rockfall. The shadow angle ranges from $10^{\circ}$ to $25^{\circ}$, with the lowest angles measured on the SW-07 (10 $)$ and SW-09 $\left(17^{\circ}\right)$ profiles. These angles are lower than the minimum rockfall shadow angle ranging from $22^{\circ}$ to $30^{\circ}$ (Rapp, 1960; Govi, 1977; Lied, 1977; Hungr and Evans, 1988; Evans and Hungr, 1993). Therefore, it can be assumed that slope debris were deposited beyond the rockfall runout zone by another process. The hypothetical travel distance for the farthest debris ranges from 105 to $318 \mathrm{~m}$, with the longest distances measured in the downstream part of the SW side.

In June 2018, numerous dirty snow-avalanche deposits were observed on the SW side, but their terminus rarely exceeded the 


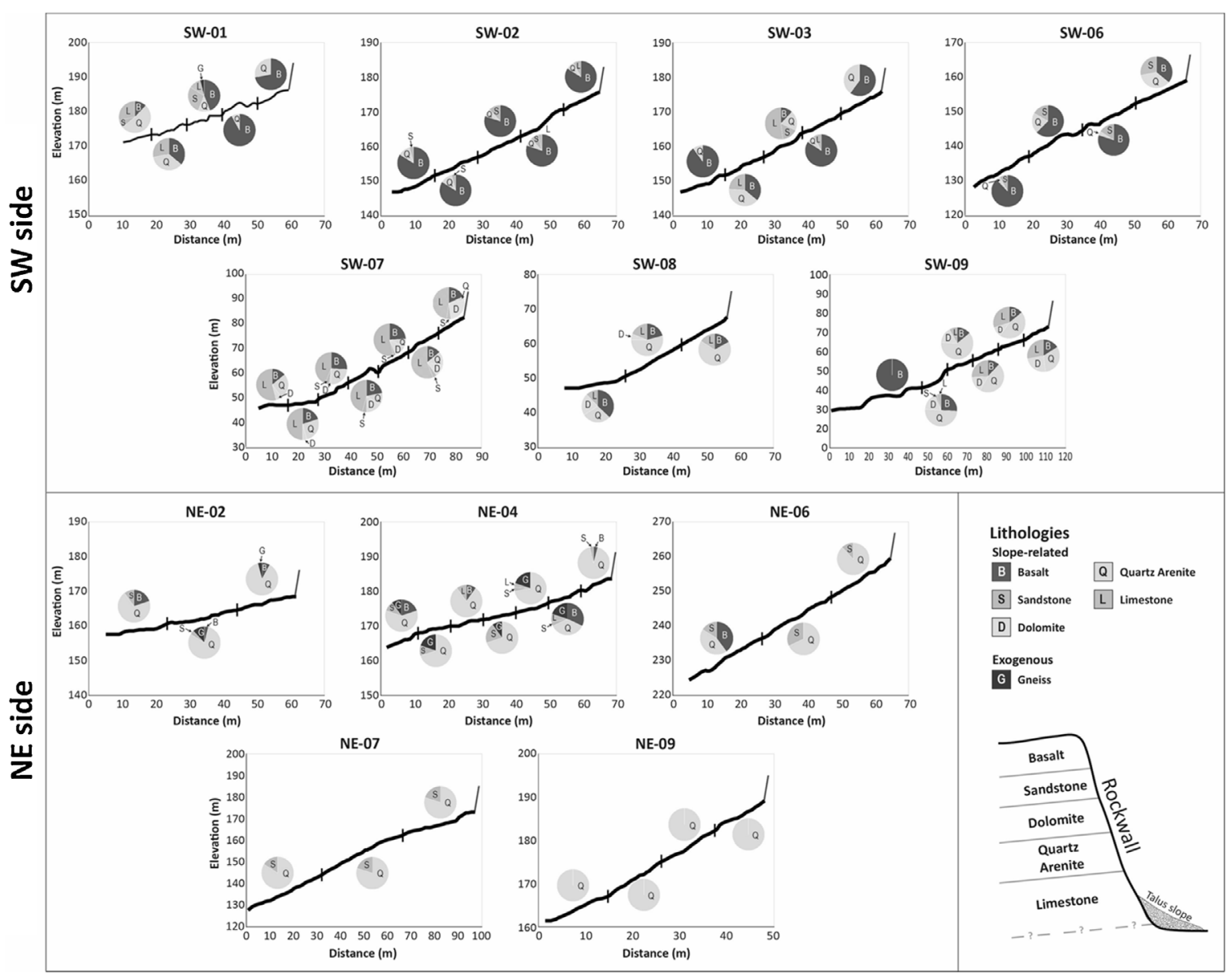

Fig. 6. Proportion of the different lithologies along the talus slope.

talus slope, thus supporting the assumption that snow-avalanche runout is generally limited to the foot of the talus. However, longer runout was observed for clean snow avalanches occurring in February through April. Extreme snow avalanche runout cannot be documented at this stage in the valley.

Tree-ring counting on 11 black spruce (Picea mariana) samples, dating back to 1900-1930, and located at the foot of the SW-07 and SW-08 profiles, showed clear signs of eccentric growth, such as the formation of reaction wood during their lifespan. As these reaction wood periods are not significantly concomitant from one tree to another, wind or snow cover could hardly be the main controlling factors for these deformations. Instead, slope processes, such as snow avalanches, are likely causes. However, the limited number of samples does not support a precise chronology of events.

\subsection{Short-term slope dynamics}

Analysis of the photographs from the three automatic cameras has documented the slope dynamics from summer 2017 to summer 2018 , with the record of one full winter. Snow avalanches were the main gravitational processes observed, occurring from November 2017 to June 2018; snow-avalanche events occurred more frequently from the end of May 2018. During this period, most of the snow-avalanche deposits exhibited a dirty appearance, because rock debris were incorporated in the dense and humid snow. This characteristic implies a flowing motion with frequent contact with the regolith (Fig. 9a). These observations were validated in the field in June 2018, when about 20 wet snow avalanches were observed on the SW side of the valley, from June 11 to June 15.
Along the SW-07 and SW-08 profiles (TAS2), some larger rock debris ( $\sim 1 \mathrm{~m}$ a-axis) were transported and deposited downslope by snow avalanches. Other debris were observed falling onto the snow-covered talus until early July 2018, concomitant with snowavalanche events. Two significant rockfalls occurred one-hour apart on June 30 2018. Several debris could be observed sliding on the snow covered talus after their fall; they travelled $\sim 30$ m before settling at mid-slope (Fig. 9b). During the same period, only a few small snow avalanches occurred in the area covered by camera TAS3, along the SW-06 profile, and no rockfall were observed. Out of the seasonal presence of snow, no movement was observed on the slopes from the analysis of the photographs.

Based on the observations during 2017-2018, slope movements occur more frequently in the spring. Prior to June 2018, no rocky deposits on the snow cover had been observed following snowavalanches, which occurred sporadically from December 2017 to April 2018.

\section{Discussion}

\subsection{Talus slope formation}

Results from the morphometric and petrographic surveys suggest an accumulation of rock debris on the SW and NE sides resulting from successive discrete rockfalls that formed into scree slopes. The vast majority of the sampled debris is from a local source, namely the lithologies exposed on the rockwall, and they exhibit subangular to angular shapes.

Vegetation cover on the talus suggests that the most recent debris supply occurred along the SW-08, NE-06 and NE-09 pro- 


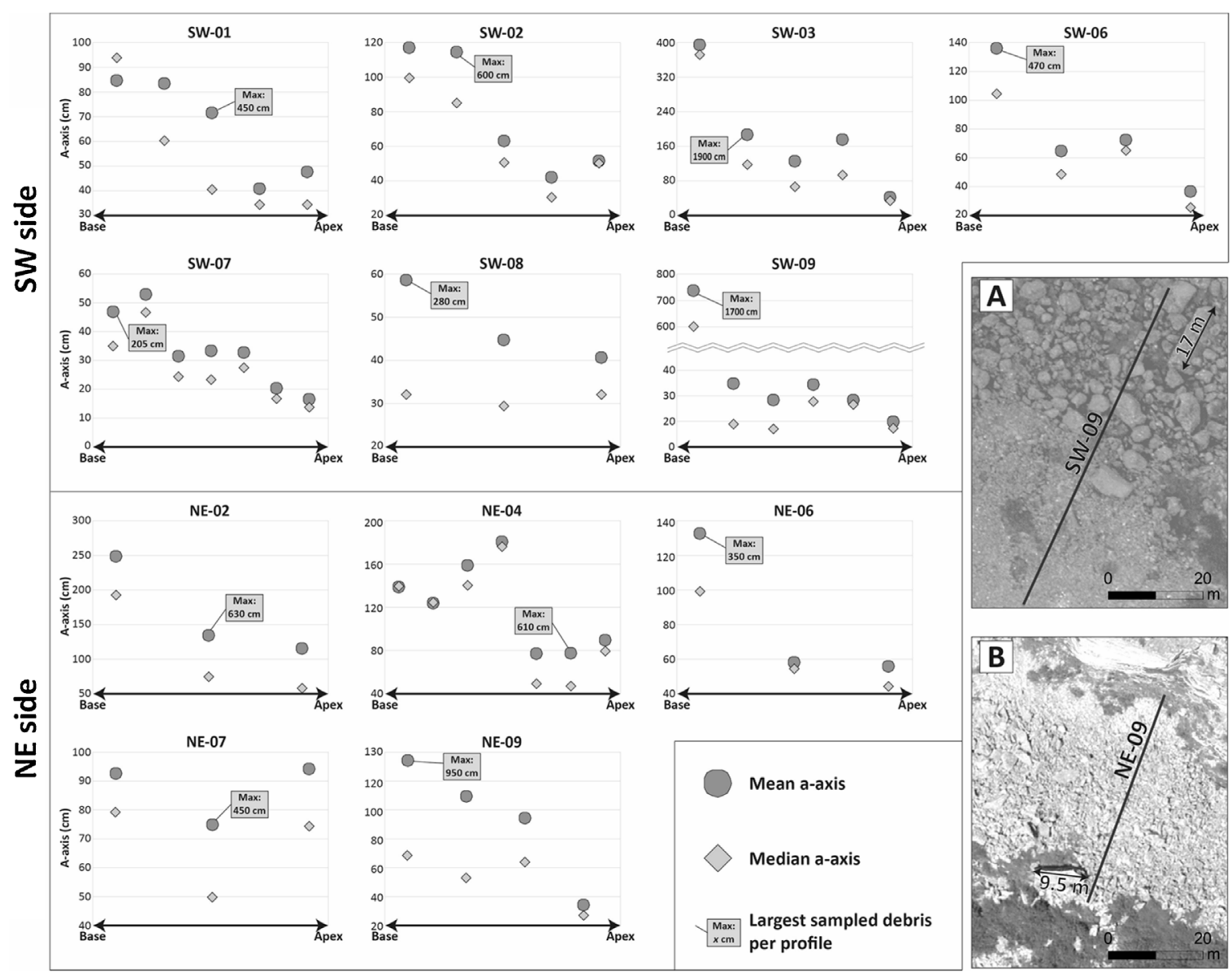

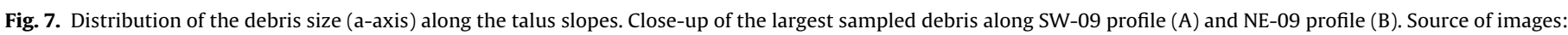
UMI orthomosaic (2010).

files, as the debris were characterized by low coverage and few or no species of lichens. The debris likely originated from recent notches formed in the rockwall above the SW-08 (Fig. 10a) and NE-09 profiles (Fig. 10b). Along the other profiles (SW-01, SW09, NE-02, NE-07), the freshest debris are found in the proximal part of the talus, presumably supplied by small-scale rockfalls. The proximal part of talus slopes generally consists of smaller debris, whereas larger debris and well-developed vegetation are found on the distal part of most of the slopes. Thus, small-scale rockfalls are unlikely to reach the base of the talus, where the accumulation is associated with large-scale rockfalls that have occurred in the past. Nevertheless, debris-size-sorting on the talus slopes, with increasing debris size toward the base, could either be attributable to rockfalls (Kirkby and Statham, 1975; Statham, 1976; Church et al., 1979) or to talus reworking by snow avalanches (Rapp, 1960; Luckman, 1978, 1988; Jomelli and Francou, 2000; Decaulne and Saemundsson, 2006). Basalt debris are larger and exhibit a more massive shape than sedimentary rock debris. They also have a higher fall height, resulting in greater travel distances toward the distal part of talus slopes, as observed along the SW-06, SW-08, SW-09, NE-02 and NE-06 profiles.

Nowadays, expanding shrub cover in Tasiapik Valley (Provencher-Nolet et al., 2014; Pelletier, 2015; Pelletier et al., 2018) could suggest a recent decline in debris supply, as rockfalls would not be frequent enough to limit shrub expansion on some slopes. On the NE side, a dense shrub cover (Fig. 10c) separates perched and basal talus slopes, while shrubs established themselves at the very base of the talus slope along the SW-07, SW-08 and SW-09 profiles (Fig. 10d). In both cases, shrubs have developed over highly weathered rock debris or rocky outcrops. Such a pattern of vegetation colonization highlights areas that lie beyond the reach of the most recent slope dynamics.

\subsection{Slope debris redistribution}

Scree slopes generally have a mean angle between $25^{\circ}$ and $30^{\circ}$, as reported by Sauchyn (1986) and Francou and Manté (1990). Steeper scree slopes $\left(>30^{\circ}\right)$ have been studied in Québec, namely in Schefferville (Andrews, 1961), in Gaspésie (Andrews, 1961; Hétu, 1995; Hétu and Gray, 2000; Germain and Hétu, 2016) and on the central islands of Wiyâshakimî Lake (Decaulne et al., 2018). Scree slopes also have a segmented profile with a steeper gradient in the proximal part and a strong basal concavity in the distal part; this slope geometry was observed on several talus slopes (Fig. 3). Given these findings, debris redistribution must be an ongoing process (Church et al., 1979; Francou and Manté, 1990) that is likely the result of snow-avalanche rework. Their impact results in a concave inflection of the talus slopes and an increase in debris size towards the base, and can be observed on most talus slopes (Rapp, 1960; Luckman, 1977, 1978; Luckman, 1988; Jomelli and Francou, 2000; Decaulne and Saemundsson, 2006). The general concavity of talus slopes suggests that surficial debris redistribution is more important than debris supply from the rockwall. Instead, smaller debris tend to be trapped in the numerous surficial cavities that are found on the talus (Statham, 1976; De Blasio and Saeter, 2010).

Photographic monitoring of a portion of the SW side found evidence of discrete rockfall events in June and July 2018, but it has mainly highlighted numerous wet and dirty snow avalanches 


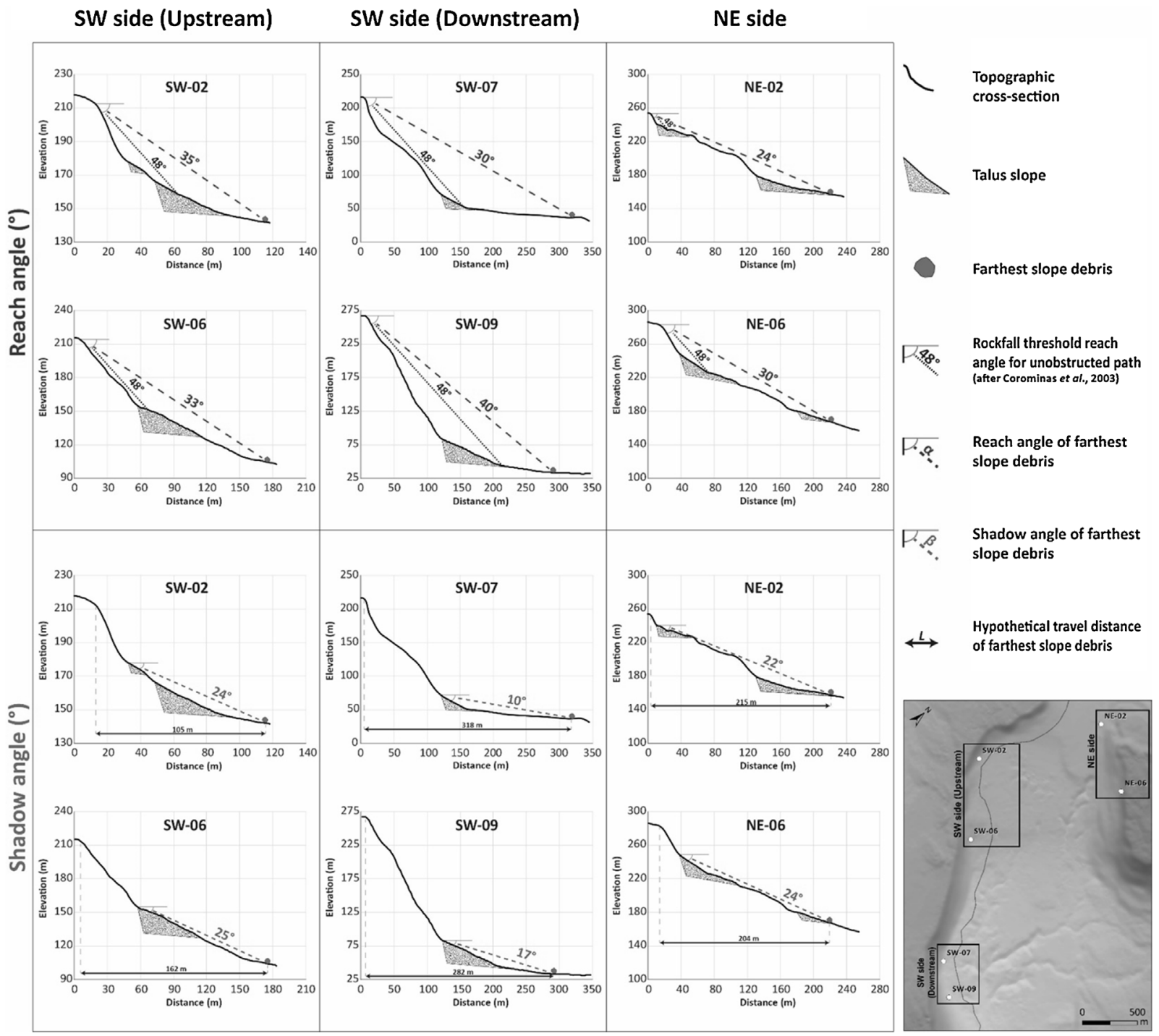

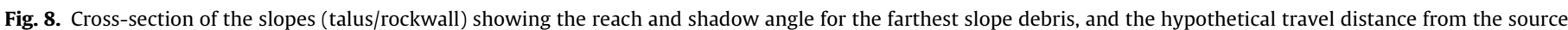
area. Source of background image: MRFP.
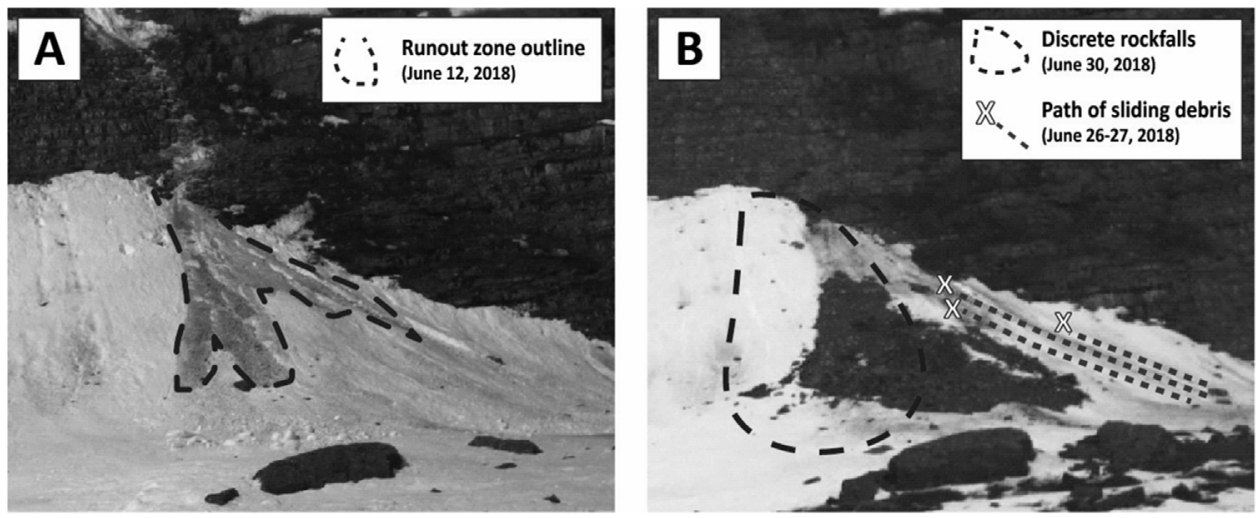

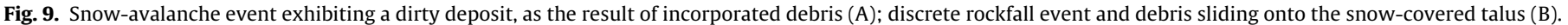

that occurred in the spring (April-June 2018). The latter have a greater erosive capacity due to higher friction at their base. They can also dislodge rock material from the bare rockwall, thus supplying the talus slope with new debris (Gardner, 1983a; Jomelli, 1999; McClung and Schaerer, 2006). During the same period, the snow-covered talus enabled recently fallen debris to slide down from the apex to mid-slope $(\sim 30 \mathrm{~m})$. Sedimentary rock debris are prone to efficient sliding because of their flattened shape (the mean flatness index for sedimentary rock debris (3.04) is higher than basalt debris (2.49) on the investigated slopes), as reported by 

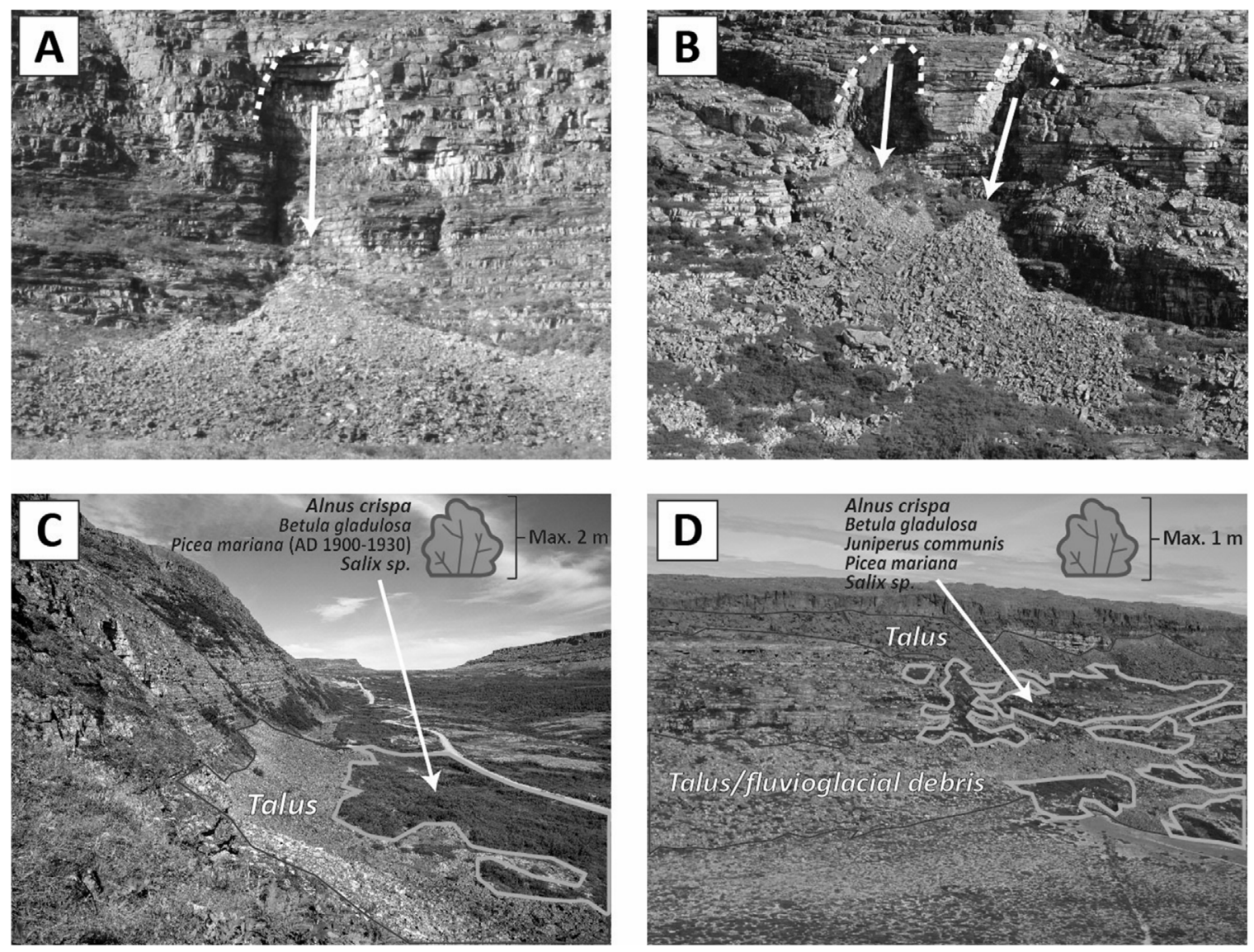

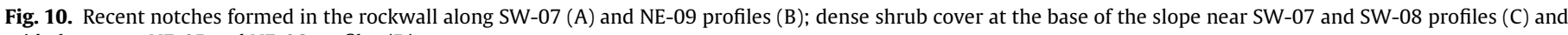
mid-slope near NE-05 and NE-06 profiles (D).

Pérez (1989) at Lassen Peak, California, and Hétu (1995) in Gaspésie, Québec.

Results of reach angle measurements have shown that scattered slope debris located far downslope originated from large-scale rockfall events along most of the talus slopes, as the angle is greater than $26^{\circ}$ (Corominas et al., 2003). Furthermore, low shadow angles, especially along the SW-07 and SW-09 profiles, provide evidence that their deposition is not entirely due to the rockfall itself, and that the transition from the talus to the valley floor requires an external transport agent (Domaas, 1994). The lowest measured shadow angle was $17^{\circ}$ in Norway (Domaas, 1994), whereas it generally ranges between $22^{\circ}$ and $30^{\circ}$ (Rapp, 1960; Govi, 1977; Lied, 1977; Hungr and Evans, 1988; Evans and Hungr, 1993). Debris falling onto an ice-covered talus slope are unlikely to be deposited at such a great distance, considering that Evans and Hungr (1993) reported a $24^{\circ}$ shadow angle for a boulder falling onto a smooth glacier. In addition, as mentioned above, the current position of the farthest lying boulders does not support the hypothesis of snow-avalancherelated transport. The abrupt slope transition (steep rockwall to valley floor) is not conducive to extreme snow-avalanche runout distances (Bakkehoi et al., 1983; McClung and Schaerer, 2006). From the base of the talus, the slope angle decreases to $\sim 4^{\circ}$, which means that a boulder that is located beyond this zone could not have been transported by a snow avalanche, being located outside of the runout zone.

Therefore, the deposition of debris would most likely be related to the deglaciation/postglacial marine episode, starting at around 8200 cal. BP in the area (Hillaire-Marcel, 1976; Lavoie et al., 2012). In particular, the presence of highly altered basalt boulders (Fig. 11) overlying littoral marine sediments would suggest that their depo- sition occurred during the regression of the Tyrrell Sea. The great distance from the surrounding slopes could then be attributable to sea-ice-related processes, such as ice rafting or ice pushing. Finally, similar processes could have distributed glacially transported rounded boulders against the talus slopes in the lower part of the NE slope, where the vast majority of the subrounded and/or gneiss debris were observed.

\subsection{Rockwall erosion}

Different dismantling mechanisms affect the various volcanosedimentary lithologies exposed on the cuesta frontslope. The top basalt layer shows a distinct columnar polygonal jointing, resulting in the detachment and subsequent fall of large ( $>5 \mathrm{~m}$ a-axis) monoliths (Fig. 12a). The edge of the basalt layer on the SW side reveals a sawtooth shape (Fig. 12b), also documented by Belzile (1984) at the Manitounuk Peninsula, $100 \mathrm{~km}$ south of Umiujaq $\left(55^{\circ} 42^{\prime} \mathrm{N}\right.$, $77^{\circ} 07^{\prime} \mathrm{W}$ ). This pattern highlights the numerous monolith falls that occurred in the past. Ongoing periglacial processes such as gelifraction and frost heave caused extensive basalt dismantling (Fig. 12c). Michaud and Dionne (1987) observed similar periglacial weathering in the basalt bedrock about $45 \mathrm{~km}$ south of Umiujaq $\left(56^{\circ} 09^{\prime} \mathrm{N}\right.$, $76^{\circ} 36^{\prime} \mathrm{W}$ ), resulting in block field development. Exhaustion of the underlying sedimentary rock layers could also cause the basalt layer to overhang the slope, eventually leading to rockfalls (Fig. 12d).

The underlying sedimentary rock layers are prone to frost shattering due to their thin-bedded sub-horizontal structure and abundant fractures exposed on the rockwall, which means that these layers are also subject to rockfalls (Frayssines and Hantz, 2006; Mateos et al., 2012; Letortu, 2013; D’Amato et al., 2016). 


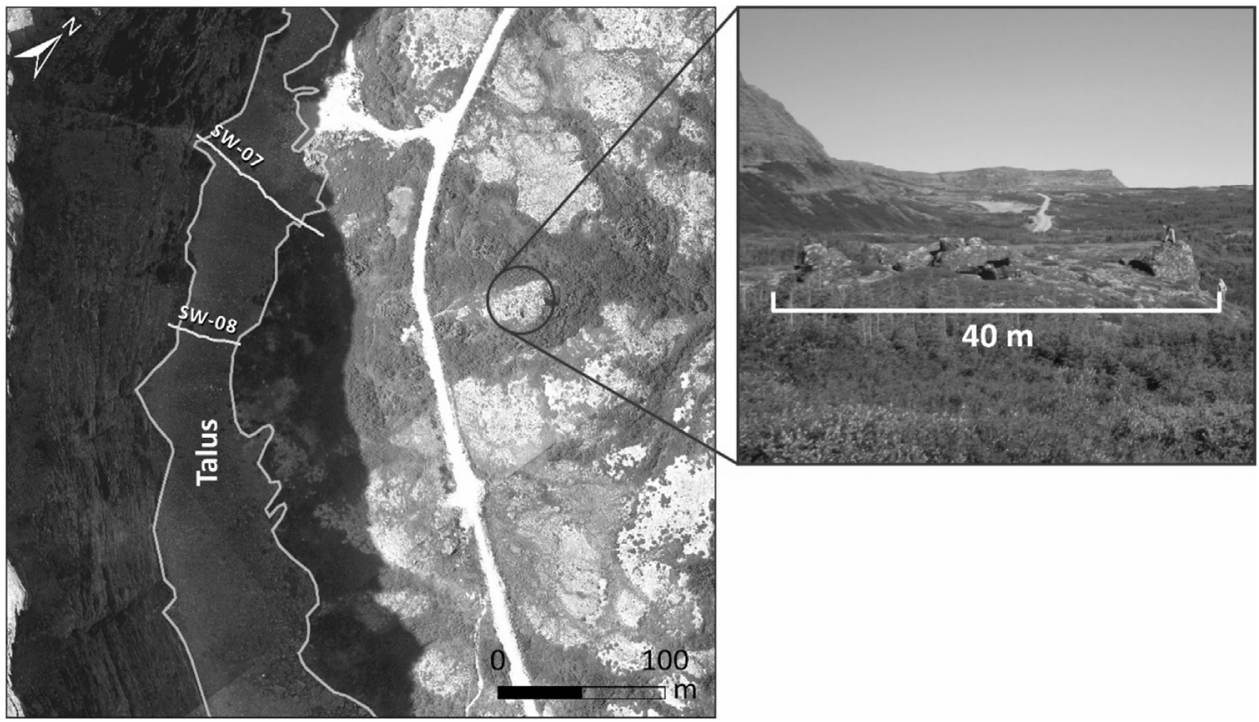

Fig. 11. Cluster of basalt boulders located $\sim 250 \mathrm{~m}$ away from the slope, overlying littoral sediments.
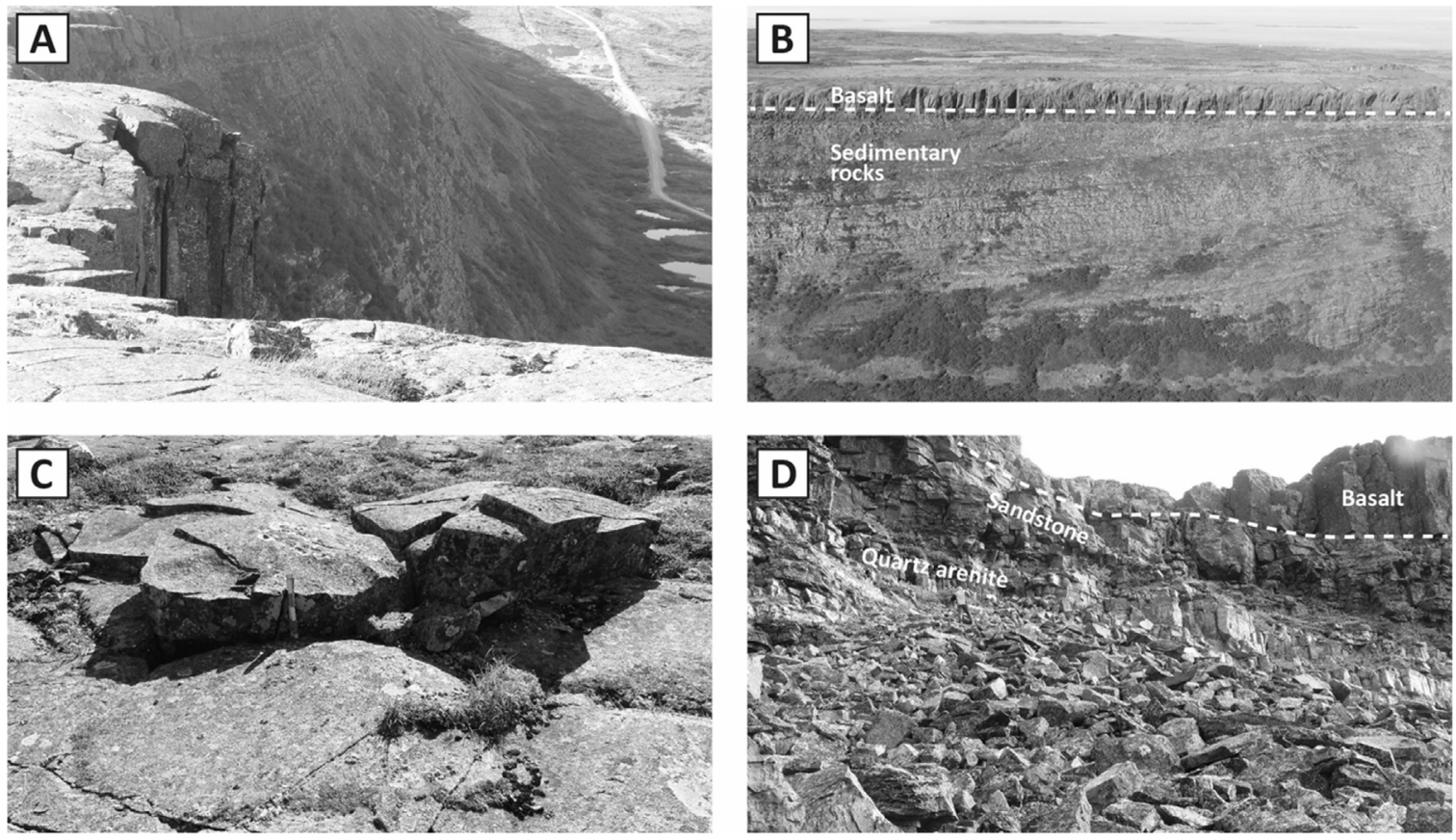

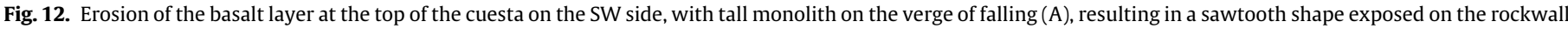

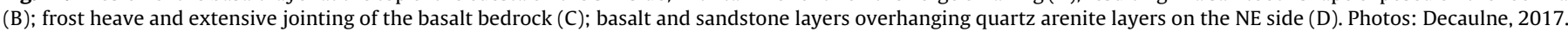

Notches have recently developed in the sedimentary rock layers, as shown on Fig. 10a-b, and have formed prominent debris cones. Subsequently, these notches will induce more discrete rockfalls from the overlying layers. Locally, rocky outcrops reveal small escarpments ( $\sim 1-5 \mathrm{~m}$ high) that supply debris for nearby talus through short fall height and distances, especially on the NE side.

Freeze-thaw weathering is known to be a major factor in rockfall triggering, especially on deglaciated rockwalls (Matsuoka and Sakai, 1999; Ballantyne, 2002; Matsuoka, 2008). The air temperature data record for the Umiujaq region (CEN, 2018), from September 2002 to June 2018, suggests that freeze-thaw cycles are on average more frequent during the spring (27 - March to June) than in autumn (19 - September to December), but with important interseasonal differences. For instance, only 9 cycles occurred in autumn 2007, followed by 34 cycles during the next spring. However, according to Hales and Roering (2007), the frequency of freeze-thaw cycles would not be a determining factor in rockfall triggering. Instead, they propose a temperature threshold $\left(-3^{\circ} \mathrm{C}\right.$ to $\left.-8^{\circ} \mathrm{C}\right)$ whereby thin water layers can infiltrate and cause segregated ice to form in the fractures, leading to the subsequent dismantling of the bedrock. The air temperature data from October 2002 to May 2018 (total of 5688 days) suggests that there were 642 days that had a mean temperature between -3 and $-8{ }^{\circ} \mathrm{C}$. They are more frequent in November (31.8\%), April (20.9\%), December (15.7\%) and May (13.9\%). At a depth of $100 \mathrm{~cm}$ in the basalt bedrock, the number of days within this threshold temperature range were more frequent in April (39.5\%), December (35.2\%) and January (11.9\%) between 2001 and 2006 (Allard et al., 2016), which shows a potential delay from autumn to winter compared to air temperature. It should be noted that slope orientation and 
altitude could influence the temperature at the surface of the rockwall, and that significant differences could be expected between the SW (NE facing) and NE sides of the valley. Nevertheless, the available freeze-thaw cycle data and temperature threshold data concur with the seasonal trend (autumn/spring) for potential rockfall activity (Gardner, 1983b; Matsuoka and Sakai, 1999; Hales and Roering, 2007; Matsuoka, 2008).

On a longer time scale, paraglacial adjustment is another rockfall-triggering factor that should be considered on deglaciated slopes (Ballantyne and Benn, 1994; Ballantyne, 2002; KellererPirklbauer et al., 2010; Cossart et al., 2013; Grämiger et al., 2017). Deglaciation occurred at about 8200 cal. BP in the study area and induced rapid rates of isostatic uplift (Hillaire-Marcel, 1976; Lajeunesse and Allard, 2003a; Lavoie et al., 2012). This in turn caused an adjustment of the rock substratum and led to stressrelease on the rock slopes resulting from the ice retreat, also known as 'debuttressing' (Ballantyne, 2002). The rockwall became susceptible to slope failures as a result of these changes.

Slope development results (Ho/Hi index) suggested that the SW side of the valley is at a younger stage of development, considering the height of the remaining rockwall compared to the step-like topography of the NE side. However, well-developed vegetation on the debris observed throughout the SW profiles (except for the SW-08 profiles) raises questions about the spatial distribution and frequency of the slope processes. The exhaustion model, in which slope failures occurring after ice retreat gradually decline until complete exhaustion of the rockwall (Cruden and Hu, 1993), would not fit in this case since local characteristics control the triggering of slope processes (i.e. periglacial processes). A bimodal/multimodal model (Krautblatter and Leith, 2015) would thus be more representative considering that the region has undergone periods of climate fluctuations since its deglaciation (i.e. Little Ice Age). However, the occurrence of extreme meteorological events, such as warm summers (Gruber et al., 2004) and heavy rainfalls (Rapp and Strömquist, 1976; Delonca et al., 2014) should also be considered, as these events can trigger rockfalls and contribute to the slope development. Furthermore, a winter/spring period with many snow avalanches could result in increased erosion on the slope, thus favoring rockfalls, and cleaning available debris accumulated in the rockwall chutes.

\section{Conclusion}

In this study, we provided evidence of slope activity resulting in talus formation in Tasiapik Valley. The results of the topographic, granulometric, morphometric, petrographic and vegetation surveys suggest that talus slopes throughout the study area are at different stages of development, with some ancient and recent slope deposits. In the field, this results in steep and concave talus slopes with fresh debris, but also coarse deposits with an openwork texture showing alteration and a more developed vegetation cover. In addition, the opposite SW and NE sides exhibit significant differences with respect to most of the parameters surveyed, which means that their evolution occurred at different time scales.

Following the last deglaciation, paraglacial adjustment could have enabled slope failures, initiating talus slope formation. Nowadays, evidence of periglacial processes (gelifraction, frost heave) that have interacted with extensive bedrock jointing has been highlighted. As a result, features such as monoliths that have detached from the basalt layer and are on the verge of falling, or notches within the sedimentary rocks, show that rockfalls could occur at any given time. However, dense vegetation cover, primarily in the form of dense shrubs, has developed on some of the slopes and at the base of the talus slopes, meaning that the slope process runout is limited at the present time.
The present-day slope dynamic has been documented with the use of automatic cameras over a one-year period during the 2017-2018 winter season. The reworking of snow avalanches on slope deposits appeared to be a significant factor in the redistribution of debris, especially in the spring when the wet snow avalanche deposits mostly consisted of dirty snow. Discrete rockfalls have occurred during the same period, and some of the fallen debris have been transported down the snow-covered talus slope.

\section{Acknowledgements}

Funding for this project was provided by the Natural Sciences and Engineering Research Council (NSERC), LabEx DRIIHM and OHMi NUNAVIK-TUKISIG, and IPEV program DeSiGN. The authors want to thank Félix Faucher, Julien Lebrun and Thorsteinn Saemundsson for their valuable help in the field and the Centre d'études nordiques (CEN) for its logistical support.

\section{References}

Allard, M., Lemay, M., 2012. Nunavik and Nunatsiavut: From Science to Policy: An Integrated Regional Impact Study (IRIS) of Climate Change and Modernization. ArcticNet Inc., Québec, Canada, 303 pp.

Allard, M., Séguin, M., 1985. La déglaciation d'une partie du versant hudsonien québécois: bassins des rivières Nastapoca, Sheldrake et à l'Eau Claire. Géographie physique et Quaternaire 39 (1), 13-24.

Allard, M., Sarrazin, D., L'Hérault, E., 2016. Borehole and near-surface ground temperatures in northeastern Canada, v. 1.4 (1988-2016). In: Nordicana D8., http:// dx.doi.org/10.5885/45291SL-34F28A9491014AFD.

Andrews, J., 1961. The development of scree slopes in the English Lake District and central Quebec-Labrador. Cahiers de géographie du Québec 5 (10), 219-230.

Projet de parc national des Lacs-Guillaume-Delisle-et-à-l'Eau-Claire. État des connaissances. Administration régionale Kativik, Service des ressources renouvelables, de l'environnement, de territoire et des parcs, Section des parcs, Kuujjuaq, Québec.

Bakkehoi, S., Domaas, U., Lied, K., 1983. Calculation of snow avalanche runout distance. Ann. Glaciol. 4, 24-29.

Ballantyne, C.K., 2002. Paraglacial geomorphology. Quat. Sci. Rev. 21 (18-19), 1935-2017.

Ballantyne, C.K., Benn, D.I., 1994. Paraglacial Slope Adjustment and Resedimenfation following Recent Glacier Retreat, Fåbergstølsdalen, Norway. Arct. Alp. Res. 26 (3), 255-269.

Bégin, C., Filion, L., 1985. Analyse dendrochronologique d'un glissement de terrain de la région du Lac à l’Eau Claire (Québec nordique). Can. J. Earth Sci. 22 (2), $175-182$.

Belzile, M.C., 1984. Les versants rocheux périglaciaires à la presqu'île des Manitounouc Kuujjarapik, Nouveau-Québec. Mémoire de maîtrise. Département de géographie, Université Laval.

Bérubé, J., 2000. Rapport d'enquête publique sur les circonstances des décès survenus à Kangiqsualujjuaq, Nouveau-Québec le premier Janvier 1999. Gouvernement du Québec, Bureau du coroner.

Bhiry, N., Decaulne, A., Bourgon-Desroches, M., 2019. Development of a subarctic peatland linked to slope dynamics at Lac Wiyâshâkimî (Nunavik, Canada). Holocene 29 (9), 1459-1467.

Cailleux, A., 1947. L'indice d'émoussé des grains de sable et grès. Revue de Geomorphologie Dynamique 3, 78-87.

CEN, 2018. Climate station data from the Umiujaq region in Nunavik, Quebec, Canada, v. 1.6 (1997-2018). In: Nordicana D9., http://dx.doi.org/10.5885/ 45120SL-067305A53E914AF0.

Chandler, F.W., 1988. The Early Proterozoic Richmond Gulf Graben, East Coast of Hudson Bay, Quebec, Vol. 362. Geological Survey of Canada.

Chandler, F.W., Schwarz, E.J., 1980. Tectonics of the Richmond Gulf Area, Northern Quebec - a hypothesis. In: Current Research, Part C, Paper 80-1C. Geological Survey of Canada, pp. 59-68.

Church, M., Stock, R.F., Ryder, J.M., 1979. Contemporary sedimentary environments on Baffin Island, NWT, Canada: debris slope accumulations. Arct. Alp. Res. 11 (4), $371-401$

Corominas, J., Copons, R., Vilaplana, J.M., Altimir, J., Amigó, J., 2003. Integrated landslide susceptibility analysis and hazard assessment in the principality of Andorra. Nat. Hazards 30 (3), 421-435.

Cossart, E., Mercier, D., Decaulne, A., Feuillet, T., 2013. An overview of the consequences of paraglacial landsliding on deglaciated mountain slopes: typology, timing and contribution to cascading fluxes. Quaternaire. Revue de l'Association française pour l'étude du Quaternaire 24 (1), 13-24.

Cruden, D.M., Hu, X.Q., 1993. Exhaustion and steady state models for predicting landslide hazards in the Canadian Rocky Mountains. Geomorphology 8 (4), 279-285.

D’Amato, J., Hantz, D., Guerin, A., Jaboyedoff, M., Baillet, L., Mariscal, A., 2016. Influence of meteorological factors on rockfall occurrence in a middle mountain limestone cliff. Nat. Hazards Earth Syst. Sci. 16 (3), 719-735. 
De Blasio, F.V., Sæter, M.B., 2010. Properties of talus slopes composed of flat blocks. Norsk Geografisk Tidsskrift-Norwegian J. Geogr. 64 (2), 85-93.

Decaulne, A., Saemundsson, T., 2006. Geomorphic evidence for present-day snowavalanche and debris-flow impact in the Icelandic Westfjords. Geomorphology 80 (1-2), 80-93.

Decaulne, A., Bhiry, N., Lebrun, J., Veilleux, S., Sarrazin, D., 2018. Geomorphic evidence of Holocene slope dynamics on the Canadian shield-a study from Lac à l'Eau-Claire, western Nunavik. Écoscience 25 (4), 343-357.

Delonca, A., Gunzburger, Y., Verdel, T., 2014. Statistical correlation between meteorological and rockfall databases. Nat. Hazards Earth Syst. Sci. 14 (8), 1953-1964.

Domaas, U., 1994. Geometrical Methods of Calculating Rockfall Range. Norwegian Geotechnical Institute, Report, 585910(1)

Eaton, D.W., Darbyshire, F., 2010. Lithospheric architecture and tectonic evolution of the Hudson Bay region. Tectonophysics 480 (1), 1-22.

Evans, S.G., Hungr, O., 1993. The assessment of rockfall hazard at the base of talus slopes. Can. Geotech. J. 30 (4), 620-636.

Fortier, R., 2017. Groundwater monitoring network from the Umiujaq region in Nunavik, Quebec, Canada, v. 1.3 (2012-2016). In: Nordicana D19., http://dx.doi org/10.5885/45309SL-15611D6EC6D34E23.

Francou, B., 1988. L'éboulisation en haute-montagne - Andes et Alpes -, six contributions à l'étude du système corniche-éboulis en système périglaciaire. Thèse d'État, Université Paris, 7.

Francou, B., Manté, C., 1990. Analysis of the segmentation in the profile of Alpine talus slopes. Permafr. Periglac. Process. 1 (1), 53-60.

Fraser, C., Hill, P.R., Allard, M., 2005. Morphology and facies architecture of a falling sea level strandplain, Umiujaq, Hudson Bay, Canada. Sedimentology 52 (1), $141-160$

Frayssines, M., Hantz, D., 2006. Failure mechanisms and triggering factors in calcareous cliffs of the Subalpine Ranges (French Alps). Eng. Geol. 86 (4), 256-270.

Gardner, J.S., 1983a. Observations on erosion by wet snow avalanches, Mount Rae area, Alberta, Canada. Arct. Alp. Res. 15 (2), 271-274.

Gardner, J.S., 1983b. Rockfall frequency and distribution in the Highwood Pass area canadian Rocky Mountains. Zeitshrift fur Geomorphologie, NF 27, 311-324.

Germain, D., 2016. Snow avalanche hazard assessment and risk management in northern Quebec, eastern Canada. Nat. Hazards 80 (2), 1303-1321.

Germain, D., Martin, J., 2012. The vulnerability of northern cities to weather-related hazards: case studies from the Province of Quebec, eastern Canada. Adv. Environ. Res. 22, 143-160.

Germain, D., Hétu, B.,2016. Hillslope processes and related sediment fluxes on a finegrained scree slope of Eastern Canada. In: Source-to-Sink Fluxes in Undisturbed Cold Environments., pp. 79-95.

Govi, M., 1977. Photo-interpretation and mapping of the landslides triggered by the Friuli earthquake (1976). Bull. Int. Assoc. of Eng. Geol.-Bulletin de l'Association Internationale de Géologie de l'Ingénieur 15 (1), 67-72.

Grämiger, L.M., Moore, J.R., Gischig, V.S., Ivy-Ochs, S., Loew, S., 2017. Beyond debuttressing: mechanics of paraglacial rock slope damage during repeat glacia cycles. J. Geophys. Res. Earth Surf. 122 (4), 1004-1036.

Gruber, S., Hoelzle, M., Haeberli, W., 2004. Permafrost thaw and destabilization of Alpine rock walls in the hot summer of 2003. Geophys. Res. Lett. 31 (13).

Guimont, P., Laverdiere, C., The Coastline of Canada, SB McCann (edit.), Geological Survey of Canada, Paper, 80-10 1980. Le sud-est de la mer d'Hudson: un relief de cuesta.

Hales, T.C., Roering, J.J., 2007. Climatic controls on frost cracking and implications for the evolution of bedrock landscapes. J. Geophys. Res. Earth Surf. 112 (F2)

Hétu, B., 1995. Le litage des Éboulis Stratifiés Cryonivaux en Gaspésie (Québec Canada): Rǒle de la Sédimentation Nivéo-Éolienne et des Transits Supranivaux. Permafr. Periglac. Process. 6 (2), 147-171.

Hétu, B., Gray,J.T., 2000. Effects of environmental change on scree slope development throughout the postglacial period in the Chic-Choc Mountains in the northern Gaspé Peninsula, Québec. Geomorphology 32 (3-4), 335-355.

Hillaire-Marcel, C., 1976. La déglaciation et le relèvement isostatique sur la côte est de la baie d'Hudson. Cahiers de géographie du Québec 20 (50), 185-220.

Hungr, O., Evans, S.G., 1988. Engineering evaluation of fragmental rockfall hazard. In: Proceedings. of 5th International Symposium on Landslides, Lausanne, 1988 pp. 685-690

Jenks, G.F., 1967. The data model concept in statistical mapping. International Yearbook of Cartography, vol. 7.,pp. 186-190.

Jomelli, V., 1999. Dépôts d'avalanches dans les Alpes françaises: géométrie, sédimentologie et géodynamique depuis le Petit Age Glaciaire. Géographie physique et Quaternaire 53 (2), 199-209.

Jomelli, V., Francou, B., 2000. Comparing the characteristics of rockfall talus and snow avalanche landforms in an Alpine environment using a new methodological approach: massif des Ecrins, French Alps. Geomorphology 35 (3-4), 181-192.

Kellerer-Pirklbauer, A., Proske, H., Strasser, V., 2010. Paraglacial slope adjustmen since the end of the Last Glacial Maximum and its long-lasting effects on secondary mass wasting processes: Hauser Kaibling, Austria. Geomorphology 120 $(1-2), 65-76$

Kirkby, M.J., Statham, I., 1975. Surface stone movement and scree formation. J. Geol. 83 (3), 349-362

Krautblatter, M., Leith, K., 2015. In: Huggel, C., Carey, M., Clague, J.J., Kaab, A. (Eds.), Glacier-and Permafrost-Related Slope Instabilities. The High-Mountain Cryosphere. , pp. 147-165.
Krumbein, W.C., 1941. Measurement and geological significance of shape and roundness of sedimentary particles. J. Sediment. Res. 11 (2), 64-72.

Lajeunesse, P., Allard, M., 2003a. Late quaternary deglaciation, glaciomarine sedimentation and glacioisostatic recovery in the Rivière Nastapoka area, eastern Hudson Bay, Northern Québec. Géographie physique et Quaternaire 57 (1), 65-83.

Lajeunesse, P.,Allard, M., 2003b. The Nastapoka drift belt, eastern Hudson Bay: implications of a stillstand of the Quebec-labrador ice margin in the Tyrrell Sea at 8 ka BP. Can. J. Earth Sci. 40 (1), 65-76.

Lavoie, C., Allard, M., Duhamel, D., 2012. Deglaciation landforms and C-14 chronology of the Lac Guillaume-Delisle area, eastern Hudson Bay: a report on field evidence. Geomorphology 159, 142-155.

Letortu, P., Doctoral dissertation 2013. Le recul des falaises crayeuses hautnormandes et les inondations par la mer en Manche centrale et orientale: de la quantification de l'aléa à la caractérisation des risques induits. Université de Caen Basse-Normandie.

Lied, K., 1977. Rockfall problems in Norway. ISMES Publication 90, 51-53.

Lied, K., Domaas, U., 2000. Avalanche Hazard Assessment in Nunavik and on Cotenord, Quebec, Canada. Norwegian Geotechnical Institute.

Luckman, B.H., 1977. The geomorphic activity of snow avalanches. Geogr. Ann. Ser A Phys. Geogr. 59 (1-2), 31-48.

Luckman, B.H., 1978. Geomorphic work of snow avalanches in the canadian Rocky Mountains. Arct. Alp. Res. 10 (2), 261-276

Luckman, B., 1988. Debris accumulation patterns on talus slopes in Surprise Valley, Alberta. Géographie physique et Quaternaire 42 (3), 247-278.

Marion, J., Filion, L., Hétu, B., 1995. The Holocene development of a debris slope in subarctic Québec, Canada. Holocene 5 (4), 409-419.

Mateos, R.M., García-Moreno, I., Azañón, J.M., 2012. Freeze-thaw cycles and rainfall as triggering factors of mass movements in a warm Mediterranean region: the case of the Tramuntana Range (Majorca, Spain). Landslides 9 (3), 417-432.

Matsuoka, N., 2008. Frost weathering and rockwall erosion in the southeastern Swiss Alps: long-term (1994-2006) observations. Geomorphology 99 (1-4), 353-368.

Matsuoka, N., Sakai, H., 1999. Rockfall activity from an alpine cliff during thawing periods. Geomorphology 28 (3-4), 309-328.

McClung, D., Schaerer, P.A., 2006. The Avalanche Handbook. The Mountaineers Books.

Ménard, É., Allard, M., Michaud, Y., 1998. Monitoring of ground surface temperatures in various biophysical micro-environments near Umiujaq, eastern Hudson Bay, Canada. In: In Proceedings of the 7th International Conference on Permafrost. Canada, Yellowknife, pp. 723-729.

Michaud, Y., Dionne, J.C., 1987. Altération des substrats rocheux et rôle du soulèvement gélival dans la formation des champs de blocaille, en Hudsonie. Géographie physique et Quaternaire 41 (1), 7-18.

Payette, S., 1983. The forest tundra and present tree-lines of the northern QuébecLabrador peninsula. Nordicana 47, 3-23.

Pelletier, M., Master thesis 2015. Geomorphological, Ecological and Thermal Time Phase of Permafrost Degradation, Tasiapik, Nunavik (Québec, Canada). Université Laval.

Pelletier, M., Allard, M., Levesque, E., 2018. Ecosystem changes across a gradient of permafrost degradation in subarctic Québec (Tasiapik Valley, Nunavik, Canada). Arct. Sci. 0, 1-26.

Pérez, F.L., 1989. Talus fabric and particle morphology on Lassen Peak, California. Geogr. Ann. Ser. A Phys. Geogr. 71 (1-2), 43-57.

Provencher-Nolet, L., Bernier, M., Lévesque, E., 2014. Quantification des changements récents à l'écotone forêt-toundra à partir de l'analyse numérique de photographies aériennes. Écoscience 21 (3-4), 419-433.

Rapp, A., 1960. Recent development of mountain slopes in Kärkevagge and surroundings, northern Scandinavia. Geogr. Ann. 42 (2-3), 65-200.

Rapp, A., Strömquist, L., 1976. Slope erosion due to extreme rainfall in the Scandinavian mountains. Geogr. Ann. Ser. A Phys, Geogr. 58 (3), 193-200.

Sauchyn, D.J., 1986. Particle size and shape variation on alpine debris fans, Canadian Rocky Mountains. Phys. Geogr. 7 (3), 191-217.

Schneiderhöhn, P., 1954. Eine vergleichende Studie über Methoden zur quantitativen Bestimmung von Abrundung und Form an Sandkörnern (Im Hinblick au die Verwendbarkeit an Dünnschliffen.). Heidelberger Beiträge zur Mineralogie und Petrographie 4 (1-2), 172-191.

Sellier D., 1992. Évolution comparée de versants quartzitiques des Highlands d'Écosse et de Norvège centrale (Rates of quartzitic slopes evolution in the scottish Highlands and central Norway). Bulletin de l'Association de Géographes Français 69 (3), 236-241.

St-Cyr, N., 1986. Formation et évolution des versants rocheux des îles centrales du lac à l'Eau Claire, Québec subarctique. Mémoire de maîtrise. Département de géographie, Université Laval.

Statham, I., 1976. A scree slope rockfall model. Earth Surf. Process. 1 (1), 43-62.

Stockwell, C.H., McGlynn, J.C., Emslie, R.F., Sanford, B.V., Norris, A.W., Donaldson, J.A. Fahrig, W.F. Currie, K.L., (1979). Géologie du Bouclier canadien. In Douglas, R. J W. \& Tremblay, L. P., Géologie et ressources minérales du Canada (p. 117-119). Energie, mines et ressources Canada. 